\title{
Os mecanismos de funcionamento do "padrão-ouro": uma visão crítica *
}

\section{Cláudio Gontijo **}

\section{Resumo}

Este artigo examina os mecanismos de funcionamento do padrão-ouro, apontando as inconsistências da visão tradicional, baseada no mecanismo de fluxos de ouro/ajuste de preços de Hume, que ignora a chamada lei de refluxo de Adam Smith e as propriedades inerentes a um regime de moeda-mercadoria. Evitando o caráter apriorístico e excessivamente estilizado da maioria das análises, busca elucidar os mecanismos de ajustamento tendo como base a história econômica, o que torna o assunto mais compreensível, assim como mais concreto e menos desconectado da realidade efetiva, cuja explicação tem apresentado várias dificuldades para a ortodoxia, conforme reconhecido por inúmeros autores.

Palavras-chave: Padrão-ouro; Lei do refluxo; Fluxos de ouro/Ajuste de preços de Hume; Ajuste do balanço de pagamentos; Moeda-mercadoria.

\section{Abstract \\ The working mechanisms of the "gold standard": a critical view}

This article analyses the workings of the gold standard. It points out the inconsistencies of the traditional view, based on Hume's price-specie flow mechanism, which ignores Adam Smith's "law of reflux" and the properties of a commodity money regime. Avoiding the aprioristic and excessively stylized character of the majority of analyses, the study discusses the adjustment mechanisms based on real economic history. This makes the issue easier to understand, as well as more concrete and less disconnected from effective reality, which, as recognized by many authors, is very difficult to explain from an orthodox perspective.

Keywords: Gold standard; Law of reflux; Hume's price-specie flow mechanism; Balance of payment adjustment; Commodity money.

JEL F41, N1.

\section{Introdução}

Não obstante ter sido "comparativamente um breve episódio da história [econômica] mundial" (Yeager, 1976, p. 299), o padrão-ouro retém ainda hoje, quase um século depois de seu término, o interesse dos economistas, como demonstram os inúmeros artigos que, nas últimas décadas, procuraram, de uma maneira ou de outra,

\footnotetext{
${ }^{*}$ Trabalho recebido em 19 de novembro de 2010 e aprovado em 5 de novembro de 2012.

** Professor da Faculdade de Ciências Econômicas da Universidade Federal de Minas Gerais (FACE/ UFMG), Belo Horizonte, MG, Brasil. E-mail: gontijo@,face.ufmg.br.
} 
reexaminá-lo ou que, por diversos motivos, a ele fizeram referência ${ }^{1}$. Numa visão idealizada, esse regime monetário continua sendo um modelo normativo, um ideal de referência, visto que, segundo muitos, além de proporcionar estabilidade à taxa de câmbio (Eichengreen, 1985, p. 6), representava "um mecanismo extraordinariamente durável e eficiente de assegurar a estabilidade dos preços e da renda, aliviar as pressões sobre o balanço de pagamentos e de reconciliar as ações das autoridades monetárias" (Eichengreen, p. 2) ${ }^{2}$. De mais a mais, operava automaticamente ${ }^{3}$, limitando o escopo das políticas discricionárias e forçando, assim, as autoridades a harmonizar, de fato, as políticas monetárias (Cunliffe Committee on Currency and Foreign Excheanges After the War, 1918). Finalmente, como salientado por Scammell (1968, p. 118), ainda hoje é difundida a crença de que "o padrão-ouro internacional conforme se desenvolveu no século dezenove dotou o mundo industrial em expansão com o mais eficiente sistema de ajustamento do balanço de pagamentos que já houve"4, de modo que se poderia dizer, com Harrod (1951, p. 231), que até hoje "não se encontrou outro sistema que opere [tão] satisfatoriamente para todos".

Por outro lado, a grande maioria dos autores que examinou o padrão-ouro assume o chamado mecanismo de fluxos de ouro/ajuste de preços de Hume, inserindo apenas a taxa de juros no mesmo, para torná-lo compatível com os movimentos internacionais de capital, como se esse mecanismo fosse aplicável a um regime de moeda-mercadoria e não pressupusesse, como se sugere a seguir, a moeda fiduciária. Mais do que isso, à medida que "a era pré 1914 se distancia no tempo, dominam cada vez mais explicações super simplificadas e descrições excessivamente idealizadas de como o padrão-ouro operava" (Bloomfield, 1959, p. 10), as quais, por seu turno, "lançam mais luz sobre o mito do padrão-ouro do que sobre a realidade histórica" (Eichengreen, 1985, p. 3).

Este trabalho pretende apontar as inconsistências da visão tradicional sobre o padrão-ouro, que ignora a chamada lei de refluxo de Adam Smith e as propriedades

(1) Conforme registra Cooper (1982, p. 43), em junho de 1981, o presidente Reagan instituiu uma Comissão do Ouro para examinar a viabilidade de se restabelecer o padrão-ouro nos Estados Unidos. Como exemplos de trabalhos escritos desde a década de 1980 sobre o padrão-ouro, tem-se, além de Cooper, os de Bordo e Schwartz (coletânea, de 1984); Bordo e Eichengreen (1985); Rockwell (coletânea de 1985); Calomiris e Hubbard (1986); Moggridge (1987); Neely e Wood (1993); Bordo (1993); Bordo e Kydland (1995); Rolnick e Weber (1997); Bordo, Choudhri e Schwartz (2002); Serrano (2002); Canjels, Prakash-Canjels e Taylor (2004); Balachandran (2008) e Chernyshoff, Jacks e Taylor (2009), entre outros.

(2) "O padrão-ouro é, geralmente, considerado o epítome de um sistema monetário internacional estável" (Eichengreen, 1995, p. 59).

(3) "A grande atração do padrão-ouro era o seu automatismo" (Aliber, 1973, p. 40).

(4) Segundo Trifflin (1968, p. 23), "as tradições e instituições monetárias do século XIX proporcionavam uma às outras um mecanismo extremamente eficiente de ajustamento mútuo das políticas monetárias e creditícias nacionais, essenciais para a manutenção da estabilidade da taxa cambial entre as moedas a longo prazo". Também Cooper (1982, p. 44) salienta as alegadas virtudes do padrão-ouro: (i) estabilidade dos preços; (ii) taxas de câmbio fixas; (iii) grande automaticidade no manejo da economia. Outro autor que reconhece as virtudes do padrão-ouro em termos da estabilidade da taxa de câmbio é Bloomfield (1995, p. 9). 
inerentes a um regime de moeda-mercadoria, procurando elucidar a "extraordinária charada" dos mecanismos de ajustamento do padrão-ouro (Moggridge, 1987, p. 3). Evitando o caráter apriorístico e excessivamente estilizado da maioria das análises, busca discutir os mecanismos de ajustamento tendo com base a história econômica efetiva, o que deve ajudar a tornar o assunto mais compreensível, assim como mais concreto e menos desconectado da realidade efetiva, que tem apresentado várias dificuldades para a explicação ortodoxa, conforme reconhecido por Whale (1937, p. 50-53), Bloomfield (1959, p. 60-62); Triffin (1968, p. 23-50) e Eichengreen (1985, p. 2), entre outros. Afinal, como aponta Bloomfield (1959, p. 61), "o padrão-ouro pré 1814 , tão simplificado e idealizado nos livros-texto e em outras obras, era um mecanismo mais complexo do que geralmente se acredita".

Divide-se este artigo em cinco seções, além desta introdução. Na seção 1 discute-se os fundamentos e a abrangência temporal do padrão-ouro, enquanto na seção seguinte realiza-se um rápido apanhado sobre suas origens e desenvolvimento. O funcionamento do padrão-ouro na perspectiva dos mecanismos do fluxo de metais/ ajuste de preços de Hume é sumarizado na seção 3, enquanto as críticas dessa abordagem são discutidas na seção seguinte. O funcionamento efetivo, fundamentado na história do mercado monetário britânico, é examinado na seção 5, enquanto a discussão das conclusões desdobra-se na última seção.

\section{Fundamentos e abrangência do padrão-ouro}

Uma das dificuldades em toda discussão sobre o padrão-ouro consiste nos critérios que permitem distingui-lo dos outros regimes monetários do ponto de vista dos mecanismos de funcionamento e da abrangência temporal. Para Eichengreen (1985, p. 3-4), por exemplo, o padrão-ouro passou a existir quando determinado número de países passou a aceitar os seus três princípios ou "regras" estruturantes, a saber:

(i) inter-conversibilidade entre a moeda doméstica e ouro a determinado preço oficial fixo, (ii) liberdade dos cidadãos de importar e exportar ouro e (iii) um conjunto de regras relacionando a quantidade de dinheiro em circulação num país ao estoque de ouro deste país ${ }^{5}$.

Segundo, então, essa abordagem, o padrão-ouro, como regime que prevaleceu numa escala global, ou melhor, que incorporou todos os países mais desenvolvidos

(5) Para Yeager (1976, p. 295), “existe um padrão-ouro internacional quando a maioria dos países mantém a conversibilidade nos dois sentidos entre ouro e suas unidades monetárias nacionais à taxas substancialmente fixas e deixam substancialmente livres de interferência as remessas de ouro para fora e para dentro do país". Observe-se a proximidade do pensamento de Bloomfield (1981, p. 452), para quem o padrão-ouro pode ser caracterizado da seguinte maneira: "a unidade monetária nacional era definida em termos de dada quantidade de ouro; o banco central ou o tesouro estavam prontos a comprar e vender ouro ao preço fixo resultante em termos da moeda nacional; o ouro era livremente cunhado e moedas de ouro formavam uma significante parte do meio circulante; e o ouro poderia ser exportado e importado livremente". 
do mundo, prevaleceu apenas de 1880 a 1914 (Bloomfield, 1959, p. 9; Eichengreen, 1985, p. 4). Na verdade, conforme salientam Yeager (1976, p. 299) e Condliffe (1950, p. 362), esse regime teria predominado plenamente apenas entre 1897 e $1914^{6}$.

Embora amplamente utilizada, essa caracterização, em primeiro lugar, não toma em consideração que, desde que os mesmos dispositivos institucionais prevaleçam, não há distinção entre os mecanismos de funcionamento monetário quando a moeda de reserva é de ouro ou de prata. Em segundo lugar, como se verá adiante, confunde dinheiro com crédito, o que obscurece o entendimento das razões pelas quais se desenvolveram crises periódicas durante a vigência do regime, assim como da lógica dessas crises. Em terceiro lugar, ignora que, mesmo sem "regras" explícitas, o próprio interesse dos agentes econômicos e os arranjos institucionais que acabaram por prevalecer relacionavam a quantidade de meios de circulação às reservas de ouro (ou prata) dos bancos. Finalmente, faz abstração de importantes elementos histórico-institucionais que tornam difícil o entendimento dos mecanismos efetivos de funcionamento do regime, inclusive do papel da discricionariedade dos agentes envolvidos.

De forma, pois, a se ampliar o entendimento do funcionamento efetivo do padrão monetário anterior a 1914, rompendo-se as barreiras artificiais colocadas pela definição tradicional, com a ampliação do seu escopo temporal e espacial, neste estudo define-se o "padrão-ouro" como o regime monetário com as seguintes características: (i) dinheiro-mercadoria (ouro e/ou prata) de livre cunhagem (sem seignoriage); (ii) plena conversibilidade da moeda de crédito emitida pelos bancos comerciais - em particular das notas bancárias e créditos em conta corrente - em moedas de ouro e/ou prata; (iii) plena liberdade de exportação/importação de moedas e de barras de ouro e/ ou prata. Ainda que, nesse sentido, o padrão-ouro teria a dimensão temporal admitida por de Cecco (1992), este artigo detém-se sob o período a partir de meados da década de 1860 , tendo em vista que, somente então, os mecanismos de arbitrage passam a operar com eficiência, como consequência do telégrafo a cabo e da unificação do mercado internacional de capitais.

\section{Origens e desenvolvimento do padrão-ouro}

Assim como no caso dos outros países, "a Inglaterra não estabeleceu o padrãoouro por qualquer ato consciente e deliberado" (Feavearyear, 1931, p. 142). Antes pelo contrário, ele resultou do desenvolvimento histórico do sistema de bancos de

(6) Na verdade, os Estados Unidos permaneceram em um regime de papel moeda inconversível entre 1862 e 1878 e a Lei do Padrão-Ouro somente foi aprovada em 1900. Os regimes monetários da China e do México eram baseados na prata e assim permaneceram no século XX (Cooper, 1982, p. 45). Por outro lado, registre-se que Yeager (1976, p. 295) reconhece que, num âmbito mais restrito, o padrão-ouro teria prevalecido aproximadamente nos 40 anos que antecederam a Primeira Guerra Mundial. Já para Rolfe e Burtle (1973, p. 23), o padrão-ouro durou de 1879 a 1914. 
emissão, que se formaram a partir de meados do século XIV, na esteira do surgimento da negociabilidade.

É claro que "os mecanismos do crédito datam das civilizações da Antigüidade" (Conant, 1915, p. 1) e as atividades bancárias têm existido desde tempos remotos. Contudo, até meados do Século XIV, os instrumentos de crédito existentes não eram papeis negociáveis - não representando, em si mesmos, prova suficiente de débito, nem poderiam ser transferidos a terceiros sem a presença de um tabelião (MacLeod, 1855, v. I, p. 351). Isto mudou com o surgimento da letra de câmbio, cujo primeiro registro histórico data de 1191 e 1199 (Scammell, 1968, p. 25), embora seu uso se tenha generalizado somente depois de $1350^{7}$. Inicialmente uma ordem de pagamento ou certificado de depósito emitido por cambistas, isto é, por "negociantes de dinheiro" (MacLeod, 1855, v. I, p. 363), mais tarde tornou-se uma forma de se obter crédito, ou seja, uma promessa de pagamento para determinado momento no futuro (Stuart Mill, 1848, p. 72-74; Jevons, 1877, p. 300; Feavearyear, 1931, p. 91-92 e 150-151; Hawtrey, 1932, p. 4-9; 1938, p. 5; 1947, p. 33; Scammell, 1968, p. 24-28; Kindleberger, 1989, p. 86-90). Nesse papel, representava inicialmente apenas a fatura a prazo que era enviada ao comprador para cobrança, mas que, devidamente endossada, podia ser repassada para terceiros ou descontada junto a um "procurador", "induzidor", "escriturário de dinheiro" ou comerciante, ou seja, a um predecessor do corretor (bill broker), ou a um estabelecimento bancário, depois que estes surgiram (Hawtrey, 1932, p. 5 e 10) ${ }^{8}$. Quer como notas de venda a prazo, como ordens de pagamento, como certificados de depósito ou como notas promissórias emitidas por comerciantes e industriais, endossadas ou não, as letras de câmbio passaram a circular amplamente, compondo, assim como o ouro e outros títulos, o meio circulante 9 .

Apesar dos bancos comerciais terem se originado de diversas formas ${ }^{10}$, Conant (1915, p. 6) salienta o papel dos cambistas de dinheiro, cuja atividade se espalhou pela Europa Ocidental com o desenvolvimento do comércio nos últimos séculos da Idade Média, tornando-se particularmente importante nas cidades italianas. A partir de determinado momento, os cambistas começaram a receber ouro e prata em depósito,

(7) De acordo com King e Gregory (1936, p. 4), a primeira referência estatutária à letra de câmbio “ocorreu em 1379, como letteres d'eschange, mas aparentemente não houve qualquer decisão legal diretamente a seu respeito até 1603". Veja-se, também, Scammell (1968, p. 25).

(8) O surgimento dos bill brokers no Reino Unido e, depois, a transformação de alguns desses em banqueiros é sumarizada por Feavearyear (1931, p. 150). Um desenvolvimento mais completo do tema pode ser encontrado em Scammell (1968, p. 27 e 115-130) e King e Gregory (1936, p. 1-34).

(9) Veja-se Stuart Mill (1848, p. 73-74); Hawtrey (1947, p. 5) e Scammell (1968, p. 25-28). Feavearyear (1931, p. 153) salienta que, no Reino Unido, as letras de câmbio "constituíam a única moeda de crédito do West Riding e Lancashire". Stuart Mill (idem, p. 75) confirma o seu amplo uso como moeda em Lancashire. O papel das letras de câmbio como meio de circulação somente decairia a partir da década de 1870, como resultado do desenvolvimento dos bancos com filiais espalhados pelo país e pelo crescente uso dos créditos bancários (King; Gregory, 1936, p. 271-275)

(10) Para bancos originados por ourives, veja-se Feavearyear (1931, p. 90-107). 
emitindo certificados, e logo passaram a emprestar dinheiro através da emissão de ordens de pagamento que, ao se tornarem à vista e ao portador, passaram a ser denominadas notas bancárias ${ }^{11}$. Em fins do século XVII, já existiam aproximadamente 25 instituições denominadas bancos na Europa (MacLeod, 1855, v. I, p. 365), mas algumas eram apenas administradoras de dívida pública e outras não emprestavam dinheiro. Mas todas aquelas que, como os Bancos de Barcelona e de Nápoles, o Banco St. George, em Gênova e os Bancos da Inglaterra e da Escócia, operavam com o desconto de letras de cambio, emitiam notas bancárias, quer contra depósitos, quer através de operações de empréstimo.

Nos países com bancos de emissão, essas notas circulavam lado a lado com as moedas metálicas e as "moedas de troco"12, as letras de câmbio e as Letras do Exchequer $^{13}$ ainda não vencidas ${ }^{14}$, veiculando a compra/venda de bens e serviços. Em relação à Inglaterra, Feavearyear (1931, p. 96; 97-98) informa que a primeira notícia referente ao uso de um certificado de depósito dos ourives para fazer pagamentos remonta a 1668 e que "pouco depois disso começou-se geralmente a se falar dos recibos [de depósitos dos ourives] como notas de caixa ou letras". Para efeitos legais, a nota bancária tornou-se ao portador em 1758 (Feavearyear, p. 99).

Registre-se que, apesar da presença do ouro, o padrão monetário da quase totalidade dos países, a começar pelo Reino Unido, estava baseado na prata, visto ser desse metal a moeda padrão de determinado peso e pureza da liga que definia a unidade monetária. Mais exatamente, embora a moeda de referência, como no caso do penny esterlino ${ }^{15}$, fosse de prata, era comum a cunhagem de moedas de ouro, como os sovereigns e guineas, que, em razão desse metal valer muito mais do que a prata, eram utilizadas nos pagamentos de grandes somas ${ }^{16}$. Todavia, com a continuada drenagem de moedas de prata para pagar as importações da Índia e da China e com o estabelecimento, em 1717, pelo então Mestre da Casa da Moeda, Isaac Newton,

(11) Segundo Scammell (1968, p. 24) "uma nota bancária é legalmente 'uma nota promissória aceita por um banqueiro, pagável contra apresentação"”.

(12) Ao contrário das moedas de ouro e prata, cujo valor dependia do valor do metal, as "moedas de troco" (token money) eram constituídas de metal sem valor e utilizadas apenas no comércio de varejo. Circulavam por conveniência - porque todos necessitavam de moedas de pequeno valor para troco - e por força legal, visto determinar a legislação de vários países que, até determinado montante, em geral reduzido, teriam de ser forçosamente aceitas, inclusive pelo Fisco. Sobre moedas de troco, veja-se Feavearyear (1931, p. 156-159). É um erro confundir, como o faz de Cecco (1992), as leis de circulação do dinheiro (moedas de ouro e prata) com as leis da circulação das "moedas de troco".

(13) O Exchequer representa os órgãos do governo do Reino Unido encarregados do gerenciamento e da coleta dos impostos e outras rendas governamentais, englobando o Fisco e o Tesouro.

(14) No caso da Inglaterra, veja-se Feavearyear (1931, p. 101, 107 e 147) e Scammell (1968, p. 25 e 28-29).

(15) O sistema monetário britânico era baseado na tealby penny de prata, moeda tornada unidade padrão pela reforma monetária de Henry II, em 1158. As grandes somas eram pagas em "libras de esterlinos", ou seja, em moedas da mesma liga que pesassem uma libra troy de metal fino.

(16) Como não havia cotação oficial do guinéu em prata, essas moedas de ouro circulavam lado a lado das moedas de prata, com o valor de troca entre elas sendo determinado pelo mercado (Rolfe; Burtle, 1973, p. 25). 
de um preço muito alto para o guinéu de ouro, em termos de prata, as moedas de prata inglesas recém cunhadas passaram a ser rapidamente retiradas da circulação e remetidas ao exterior, o que, com o tempo, levou ao seu desaparecimento no mercado interno (Rolfe e Burtle, 1973, p. 25; Cooper, 1982, p. 44). Exceto como moeda de troco, a cunhagem de moedas de prata foi abandonada completamente na Inglaterra em 1798 e a livre cunhagem do ouro foi estabelecida em 1816.

No Reino Unido, a "conversibilidade" das notas bancárias na moedamercadoria - essência do padrão-ouro - foi interrompida em 1797, em razão da drástica redução das reservas de ouro do Banco da Inglaterra, provocada pela guerra contra Napoleão, e retomada em maio de 1821. Durante esse espaço de tempo (denominado "Período de Restrição"), a Grã Bretanha esteve, de fato e de direito, num regime de moeda fiduciária, perturbado, até 1814, pela inflação e, depois, pela deflação ${ }^{17}$. Quando do retorno da plena conversibilidade, em maio de 1821, o sistema de bancos de emissão, ancorado na conversibilidade, estava solidamente estabelecido no solo britânico. Seis anos antes, já haviam se registrado na Inglaterra e em Gales 940 bancos (Scammell, 1968, p. 121-122), mas, em razão do monopólio da forma corporativa e da emissão de notas bancárias num círculo de raio de 65 milhas centrado em Londres por parte do Banco da Inglaterra assegurado pelos Bank Charter Acts de 1708 e 1742, não havia outras instituições bancárias de porte nesses países. Nas províncias, os pequenos "bancos provinciais" e, em Londres, os chamados "bancos privados", operavam principalmente, mas não exclusivamente com o desconto de letras de câmbio, que era também o negócio dos bill brokers e, mais tarde, das Casas de Desconto (bill dealers) que redescontavam esses títulos nos bancos, inclusive no Banco da Inglaterra ${ }^{18}$. Os bancos "provinciais" e "privados" também mantinham reservas exíguas, grande parte das quais em notas e depósitos no Banco da Inglaterra, ao qual recorriam para cobrir suas eventuais necessidades de liquidez. Assim como o Banco da Inglaterra, mantinham, também, Letras do Exchequer e Consols, que eram vendidos, ainda que com perdas, para cobrir eventuais necessidades de caixa. Em virtude das suas dimensões, da sua relação privilegiada como banco do governo e da absoluta confiança do público na sua solidez, o Banco da Inglaterra havia se tornado efetivamente, além de depositário de grande parte das reservas de ouro do país, no lender of last resort, ao qual os bancos e os negociantes recorriam em situações de crise.

Embora o crédito comercial há muito se encontrasse amplamente difundido e existissem bancos em vários países da Europa e nos Estados Unidos (Dunbar, 1896), não resta dúvida de que, então, o sistema financeiro britânico era o mais avançado

(17) Para um exame do Período de Restrição, veja-se Feavearyear (1931, p. 161-215).

(18) A diferença entre os bill brokers e os bill deallers é que esses últimos descontavam títulos com recursos próprios ou de terceiros, particularmente através de call money, ou seja, de depósitos à vista dos bancos. Veja-se King e Gregory (1936, p. 42, p. 69, 114, 117-119 e 121-222). 
do mundo. O motivo é que, apesar de guardar raízes anteriores a 1750, o sistema então prevalecente, assentado no crédito comercial e nos bancos de emissão dedicados principalmente ao desconto de letras de câmbio, era fruto, em grande medida, da Revolução Industrial, que avançara mais no Reino Unido. Além disso, as instituições financeiras britânicas, em particular os 'bancos provinciais' - "o componente mais importante do sistema bancário inglês do ponto de vista [da industrialização do país]" (Cameron et al., 1967, p. 15), que somavam quase 800 em 1810, não tinham sofrido os devastadores impactos das guerras napoleônicas, que causara o fechamento de bancos centenários na Europa Continental, nem muito menos os efeitos corrosivo da pressão das finanças públicas, que fizera abortar o desenvolvimento bancário em vários países, como no caso de Portugal, da Espanha e mesmo da França antes de Napoleão. Apesar de, conforme salientam Cameron et al. (idem, p. 18) e Neal (1994, p. 152), a maior parte da formação de capital durante a primeira Revolução Industrial tenha se originado da reinversão de lucros, ainda assim o sistema financeiro desempenhou papel crucial no processo, através do financiamento do capital de giro via desconto de letras de câmbio (Neal, idem).

Com o fim das guerras napoleônicas e a difusão da Revolução Industrial, assistiu-se ao acelerado desenvolvimento financeiro dos países da Europa Continental e dos EUA (Dunbar, 1896, Cameron et al., 1967, Cameron, 1972), de modo que, por volta de meados da década de 1840, haviam outros sistemas financeiros quase tão desenvolvidos quanto o britânico, a não ser em termos do financiamento do comércio internacional, que, conforme salienta Scammell (1968, p. 162), já então absorvia 14\% do desconto de letras de câmbio das instituições britânicas. Mas essa porcentagem cresceu exponencialmente durante as décadas de 1850 e 1860, de forma que o mercado londrino se tornou "mais e mais dominado pelas condições de crédito no exterior" (King; Gregory, 1903, p. 264), para o que contribuíram decisivamente o expressivo desenvolvimento do mercado de capitais e a expansão dos investimentos internacionais, no bojo da Segunda Revolução Industrial, anunciada pelo depósito da patente do alto forno Bressemer em 1855. Para tanto, contribuiu decisivamente o desenvolvimento das casas de aceite e desconto de Londres, que, ainda segundo King e Gregory (p. 280) desempenharam um papel ativo no financiamento do comércio internacional:

Nos últimos vinte e cinco anos do século dezenove, o seu uso foi grandemente estimulado, em primeiro lugar, pelo novo influxo de financiers cosmopolitas que começou depois da crise de 1866 e, mais tarde, pelo rápido aumento do número de bancos estrangeiros que acharam necessário, especialmente nos últimos anos do século, abrir escritórios em Londres.

De fato, até fins da década de 1840, apesar da forma corporativa estar firmemente estabelecida, particularmente na mineração, transporte ferroviário e hidroviário (canais), além do setor financeiro e nos serviços de utilidade pública 
(Kindleberger, 1984, p. 195-204; Hunt, 1936), as companhias de responsabilidade limitadas ainda dominavam os outros setores e dois terços dos papéis negociados na Bolsa de Valores de Londres eram títulos públicos (Michie, 1987, p. 52). Essa situação, contudo, se transformou radicalmente a partir da década de 1850, não apenas no Reino Unido (Jeffrys, 1938; Lévy, 1950, p. 82-90, 116-125, 158-162 e 164-168; Michie, 1987, p. 3-164; Morgan e Thomas, 1962, p. 125-139, 202-216, e 282-283), mas também em outros países (Edwards, 1938, p. 1-222; Hannah, 1976, p.1-116; Kindleberger, 1984, p. 206-212; Lévy, 1950, p. 3-223; Michie, 1987, p. $165-$ 248), como resultado da Segunda Revolução Industrial. Isto porque essa Revolução "testemunhou o crescimento de algumas indústrias de enormes economias de escala", tendo surgido "vastos empreendimentos, muito maiores do que tudo aquilo que havia sido visto anteriormente" (Mokyr; Strotz, 1998, p. 2), tais como a indústria química pesada, a grande siderurgia de aço, o refino de petróleo e a geração de eletricidade, para não falar nos sistemas de telefonia e de iluminação pública (Landes, 1969). Como ocorrera anteriormente com a construção de canais e as ferrovias, que, na Inglaterra, fez com que "a pressão para que o Parlamento aprovasse as sociedades anônimas se tornou intensa" (Kindleberger, 1984, p. 202), o requerimento de capital por essas novas indústrias estava muito além dos empresários individuais e das empresas fechadas de responsabilidade limitada. Como resultado, não somente se viu aprovado o Joint Stocks Companies Act de 1856, que liberou a constituição de corporações sem a prévia autorização parlamentar, mas se assistiu ao enorme crescimento do número de sociedades anônimas, que se tornariam a forma dominante de organização empresarial em poucas décadas (Hilferding, 1910; Edwards, 1938; Hannah, 1976).

Por outro lado, há muito que o mercado financeiro londrino tinha se tornado "susceptível a influências internacionais" e os investidores e casas financeiras britânicas "comprometidos com títulos e empresas estrangeiras" (King; Gregory, 1903, p. 264), até porque "por volta de meados da década de 1820, a Grã Bretanha era um expressivo exportador de capital de longo prazo" (Kindleberger, 1973, p. 75). O mesmo ocorria com o mercado parisiense, em razão de possuir a França, além de expressivo saldo em conta corrente, também "uma balança comercial adversa com outros países europeus e uma balança favorável com o Reino Unido, o qual, por sua vez, tinha um balanço desfavorável com o Continente" (Plessis, 2005, p. 42). Assim, da mesma forma que Londres se transformara no "banco do mundo", na expressão cunhada por Nathan Rotschild em 1832 (apud King; Gregory, 1903, p. 264), também Paris representava, desde a década de 1820, "uma fonte de capital para os estados e companhias ferroviárias estrangeiras, assim como um local para de compensação de pagamentos entre a Europa continental, Grã-Bretanha, e as Américas" (Saul, 2005, p. 119). Todavia, apesar desses centros que centralizavam o mercado internacional de capitais, o monopólio do financiamento do comércio internacional desde cedo esteve nas mãos dos bancos e as casas de aceite e desconto de Londres. Mas mesmo assim, 
somente a partir da década de 1850, quando, diga-se de passagem, ocorreu verdadeira revolução nas comunicações, anunciada pela conexão da Inglaterra ao Continente (1851) e à América do Norte (1858) através de cabo submarino, é que os mercados financeiros dos principais países do mundo se tornaram interconectados de forma mais estreita, favorecendo as operações de arbitrage, sem as quais os mecanismos de funcionamento do padrão funcionavam somente de forma lenta e imperfeita ${ }^{19}$.

\section{Na verdade, já}

em 1819 se havia reconhecido que um diferencial entre as taxas [de juros] do Continente e de Londres poderia, em determinados momentos, ter um importante efeito sobre as condições de crédito de Londres; e Rotschild explicaria uma década mais tarde que o prêmio sobre o ouro no Continente 'se nivelava por si mesmo' dentro de uma margem de diferença de $1 / 2$ por cento entre Hamburgo, Amsterdam e Paris. Não obstante, em dias quando mensagens até Nova York demoravam pelo menos uma quinzena (...), e, num momento em que transferências via cabo eram desconhecidas, eram impossíveis um rápido ajustamento das taxas. Mesmo no final da década de 1850 era claro que as influências internacionais sobre o mercado de desconto raramente se faziam sentir exceto em momentos de grande stress ou quando o diferencial entre as taxas de desconto em Londres e no estrangeiro tinham se tornado anormalmente grandes (...). Amplas disparidades entre as taxas eram comuns entre Londres e mesmo centros comerciais continentais altamente desenvolvidos, como Hamburgo e Paris (King; Gregory, 1903, p. 265-266).

Essa situação se alteraria radicalmente a partir de então, como consequência do crescimento exponencial da exportação de capitais, principalmente por parte do Reino Unido, da França, dos Países Baixos, da Alemanha a partir de meados da década de 1880 e dos Estados Unidos a começar em princípios do Século XX, assim como da consequente integração do mercado financeiro mundial. No caso da Grã Bretanha, se os "investimentos líquidos no exterior representavam entre 1 por cento e 1,5 por cento do PIB entre 1811 a 1850 " e 2,1\% na década de 1850, na década de 1860 essa taxa se elevou para 2,8 por cento, atingindo 4,3\% de 1870 a 1914 (Floud; McCloskey, 1994, p. 174). Como resultado, o total "de ativos no além mar cresceu de aproximadamente 7 por cento do estoque da riqueza nacional líquida em 1850 para cerca de 14 por cento em 1860 e por volta de 32 por cento em 1914" (Floud; McCloskey p. 173). Nesse ano, em que a relação total de ativos estrangeiros/PIB chegou a $20 \%$ do PIB mundial contra 7\% em 1870 (Daudin; Morys; O’Rourke, 2008, p. 3), “a Grã Bretanha era, de longe, o maior exportador de capital, com um estoque de investimentos estrangeiros atingindo US\$ 18,3 bilhões (...), contra US\$ 8,7 bilhões por parte da França" (Cassis, 2005, p. 1-2). No caso daAlemanha, o país investiu, entre 1883 e 1913, "aproximadamente 680

(19) Segundo Gregory e King (1903, p. 269), somente a partir de 1864 as taxas de câmbio passaram a ser informadas regularmente através do telégrafo por cabo. 
milhões de libras britânicas em títulos estrangeiros (...), correspondendo a uma média de 22 milhões de libras por ano" (Bersch e Kaminsky, p. 3). Isso significa que, como consequência, em 1914, "a Grã Bretanha detinha a parte do leão dos investimentos no exterior (...), 50\%, seguida pela França, com 22\%, Alemanha, com 17\%, os Países Baixos, com 3\% e os EUA com 6,5\%" (Bordo, 2000, p. 6). Todavia, "o grosso do comércio mundial era financiado através de letras de câmbio sobre Londres, com Paris desempenhando apenas uma função paralela, de suporte, principalmente no interior da Europa" (Cassis, 2005, p. 2).

Como parte dessa expansão dos investimentos internacionais, ocorreu vigoroso processo de integração financeira, o qual se deu, conforme salientado por Flandreau e Zumer (2004, p. 17), por saltos. Ainda segundo esses mesmos autores, a primeira onda de integração, mensurada através do declínio dos coeficientes de correlação entre poupança e investimento, teria ocorrido na década de 1880, tendo sido "acompanhada pelo declínio correspondente dos prêmios de retorno [(yield premiums) dos ativos financeiros $]^{20}$. Essa tendência tinha sido interrompida em 1890 quando a Argentina entrou em defaut, causando a queda da casa Baring. Os yield premiums aumentaram e se mantiveram elevados mesmo quando, mais tarde, os prêmios recuaram. Eles ficaram em patamares mínimos históricos a partir de 1900, quando a integração financeira internacional atingiu seu ponto máximo" (Flandreau e Zumer, p. 18). Na verdade, a "massiva convergência em termos de taxas de juros talvez tenha sido o fenômeno financeiro mais impressionante de fins do século XIX e inícios do século XX” (Flandreau; Zumer, p. 19).

Conforme sustentam King e Gregory (1936, p. 264), após a crise de 1866, assistiu-se ao aprofundamento crescente da internacionalização do mercado monetário britânico, que se tornou "mais e mais dominado pelas condições de crédito no exterior e proporcionalmente menos pelas necessidades puramente domésticas" ${ }^{21}$. Se, por um lado, essa internacionalização

ao tornar o dinheiro estrangeiro mais líquido, incrementou a vulnerabilidade das reservas britânicas em períodos de crise, (...) também teve efeitos benéficos, pois dos movimentos desses fundos voláteis para dentro e para fora do país em resposta a diferenciais na taxa de juros gerou-se a compreensão de que variações na taxa de juros eram uma forma altamente efetiva de controle do balanço de pagamentos (Scammell, 1968, p. 38-39).

E, reconhecendo a crescente vulnerabilidade da City resultante da internacionalização do sistema financeiro, o Banco da Inglaterra reforçou suas reservas

(20) Tradicionalmente, os indicadores de integração financeira são o declínio dos coeficientes de correlação entre as taxas de poupança e investimento, a queda dos yield premia e o aumento dos desequilíbrios em conta corrente. Para uma discussão do fenômeno, veja-se, também, Bordo (2000); Bordo; Eichengreen e Kim (1998); Daudin; Morys e O'Rourke (2008); Goetzmann, Li e Rouwenhorst (2001) e Lothian (2000, fev./abr. 2001).

(21) Veja-se Hawtrey (1938, p. 42-44). 
a partir de 1893, quando o mercado mundial foi inundado com o ouro proveniente das minas da África do Sul. Em lugar de deixar a taxa de desconto cair até equilibrar o mercado, o Banco interrompeu a redução quando essa atingiu 2\% em fevereiro de 1894, o que provocou um rápido aumento da relação reservas/passivo, que chegou a $67 \%$. O aumento das reservas reforçou ainda mais a confiança na libra esterlina - comumente considerada como "equivalente ao ouro", - naturalmente fortalecida pela posição privilegiada da Inglaterra como centro financeiro internacional, reforçando, assim, de forma sensível, o poder da taxa de juros do Banco da Inglaterra em mobilizar o capital financeiro internacional. Tornou-se comum dizer, então, que "uma taxa do Banco de 10\%, mantida por longo tempo, traria dinheiro da lua"; de forma simétrica, "uma taxa do Banco que permanecesse por um longo período abaixo da taxa de mercado traria tomadores da lua" (Feavearyear, 1931, p. 282).

Dessa maneira, assim como no caso dos demais países que se interconectaram durante o padrão-ouro, a internacionalização do mercado de Londres a partir de meados da década de 1860 "necessariamente implicou que, no longo prazo, teria de haver um equilíbrio entre as taxas [de juros] de Londres e as taxas dos demais centros líderes" (Gregory; King, p. 265), tornando cada um desses centros "simplesmente uma parte de um grande mercado internacional” (Gregory; King, p. 266). Esse processo não somente transformou Londres "em um verdadeiro mercado internacional, fazendo-o mais sensível do que nunca diante das influências externas" (Gregory; King, p. 270), mas o mesmo se verificou com todas as praças financeiras do mundo, que passaram a integrar um verdadeiro sistema, de modo que qualquer evento ocorrido em um desses centros, ou mesmo em sua área de influência, afetaria todo o conjunto. É claro que, conforme salienta Lindert (1969), o sistema era assimétrico, visto que o Reino Unido financiava seu comércio exterior em letras em libras esterlinas, enquanto os outros países também através de créditos em esterlinos, que, então, tinham de manter, juntamente com ouro, em suas reservas internacionais. Como consequência, seu poder de atrair capital através de aumentos das taxas de juros durante os períodos de déficit no balanço de pagamentos era bem menor do que Londres, que, num certo sentido, "gerenciava" o sistema ${ }^{22}$.

Com isso, concluiu-se a montagem dos mecanismos de funcionamento do padrão-ouro, que ainda hoje fascina os estudiosos. Embora, graças à lei do refluxo, como regime de dinheiro mercadoria e de moeda de crédito conversível, seja muito anterior, somente com a mobilidade do capital e a equalização das taxas de juros no cenário internacional, resultante da integração monetária alcançada a partir de meados da década de 1860, é que, num sentido restrito, se pode falar no padrão-ouro tal como ficaria consagrado na literatura.

(22) Escapa ao escopo deste trabalho discutir em detalhe a questão se o sistema era inteiramente automático, como sustentam Robert Mundell e Arthur Laffer, ou, pelo contrário, um sistema gerenciado, como defendem Ralph Hawtrey e Arthur Bloomfield, entre outros. Todavia, como se poderá depreender da leitura desse texto, ao que tudo indica, o sistema nem era inteiramente automático, nem era completamente gerenciado. 


\section{$3 \mathrm{O}$ funcionamento do padrão-ouro na perspectiva dos mecanismos do fluxo de metais/ajuste de preços de Hume}

Conforme salientado na seção introdutória, a interpretação convencional dos mecanismos de funcionamento do padrão-ouro consagrou o processo proposto por David Hume ${ }^{23}$, nele, porém, incorporando a taxa de juros como instrumento adicional de equilíbrio do balanço de pagamentos.

Segundo Hume (1752, p. 201), "os preços das mercadorias são sempre proporcionais à abundância de dinheiro", embora seja "necessário algum tempo para que o dinheiro circule por todo o Estado e seu efeito se faça sentir em todas as camadas do povo" (Hume, p. 203), intervalo que "é tão pernicioso à indústria quando diminuem o ouro e a prata, quanto lhe é vantajoso quando aumentam esses metais" (p. $204)^{24}$. Aplicada à balança comercial, essa teoria significa que os seus desequilíbrios, na medida em que implicam no aumento ou na redução do montante de dinheiro em circulação, se autoeliminam através da variação dos preços internos em relação aos preços do resto do mundo. Para exemplificar, Hume (p. 218-219) começa com a hipótese de que quarto quintos de todo o dinheiro da Grã Bretanha teria sido aniquilada durante a noite e procede acompanhando as conseqüências. Nesse caso,

os preços das mercadorias e os salários britânicos iriam cair na mesma proporção; as mercadorias britânicas iriam consequentemente superar a concorrência estrangeira, e o aumento das exportações iria ser pago em dinheiro [- ouro - ] até que o "nível do dinheiro" na Grã Bretanha fosse novamente igual ao dos países vizinhos. Assumindo em seguida que o dinheiro na Grã Bretanha fosse multiplicado por cinco durante a noite, $[. .$.$] os preços e os salários se elevariam$ tanto na Inglaterra que nenhum país estrangeiro poderia comprar mercadorias britânicas; em compensação, ficariam comparativamente tão baratas que seriam importadas em grandes quantidades. Consequentemente, haveria um fluxo de dinheiro para fora da Inglaterra até que estivesse no nível dos outros países (Viner, 1937, cap. VI, p. 292).

Mais exatamente, um superávit na balança de comércio exterior significaria entrada de ouro, pois no padrão-ouro a taxa de câmbio era fixa ou variava dentro de uma banda estreita (entre os "pontos do ouro") em torno à taxa de câmbio de paridade, determinada pela relação entre os pesos em ouro fino das diferentes moedas (Hawtrey, 1847, p. 36-37). O aumento das reservas de ouro, por sua vez, induzia os bancos a

(23) Note-se que, conforme salientou Vickers (1959, p. 218), "vários outros autores anteriores, como, por exemplo, Vanderlint e Cantillon, assim como também Isaac Gervaise, tinham formulado claramente a teoria do mecanismo de auto ajustamento sobre o qual a fama de Hume tem dependido tão frequentemente". Engana-se, portanto, Angell (1925, p. 24), quando afirma que "Hume foi o primeiro a aplicar explicitamente e com sucesso a teoria quantidativa da moeda não apenas a um país isolado, mas ao universo dos países comerciando uns com os outros". A esse respeito, veja-se, também, Flanders (1989, p. 7, nota de rodapé 2) e Laughlin (1903, p. 110-119).

(24) Como esclarece Laughlin (1903, p. 232), Hume "modificou a teoria quantitativa da moeda, tal como formulada por Montesquieu, confinando a à moeda em circulação e aos bens no mercado". 
expandir a oferta de moeda e o conseqüente "aumento da quantidade de moeda em circulação eleva[ria] o nível de preços internos, o que afeta[ria] negativamente o saldo comercial externo da economia" (Gonçalvez; Baumann; Prado e Canuto, 1998, cap. 15, p. 276 $)^{25}$. Como conseqüência, desapareceria o superávit no comércio exterior. Inversamente,

como resultado do déficit em suas transações com o exterior o país demandar[ia] uma quantidade maior de ouro para fazer face aos seus compromissos externos. Esse processo reduz[iria] o estoque de reservas (ouro) disponíveis, afetando negativamente a oferta de moeda, até o ponto em que essa oferta retorn[asse] ao seu nível original (idem) ${ }^{26}$.

Embora alguns autores tenham formulado o mecanismo de ajuste apenas em termos de resultado de interações entre a balança de comércio exterior, a oferta de moeda e o nível de preços, o modelo tradicional de funcionamento do padrão-ouro cedo incorporou os efeitos das flutuações da quantidade de moeda sobre a renda, variável que também influenciaria a balança de comércio exterior. Aliás, no próprio texto de Hume não havia distinção em termos dos efeitos de uma variação da oferta de moeda sobre as quantidades comercializadas e sobre os preços, sendo de se cogitar que ambos se fizessem sentir, como, aliás, seria sustentado por Friedman (1958, p. 179), partidário da teoria quantitativa da moeda de Hume. Não verdade, essa incorporação deixou o mecanismo praticamente inalterado, não sendo, portanto, necessário examiná-lo em maior detalhe.

Coisa diversa ocorreu com a incorporação ao modelo tradicional de ajustamento do balanço de pagamentos do padrão-ouro dos efeitos das variações da oferta monetária sobre a taxa de juros e dessa última variável sobre o balanço de pagamentos $^{27}$. Essa modificação tornou-se imprescindível, pois, conforme verificado na seção 2, "à medida em que o século dezenove terminava e os mercados de capital mundiais se tornavam mais integrados, aumentava o papel da mobilidade do capital, ao ponto que passou a ser considerado como o mecanismo de ajustamento dominante" (Bordo, 1984, p. 25). De mais a mais, como atesta Whale (1937, p. 49), se, por um lado, "as mudanças [no volume] da circulação [monetária resultantes da entrada/ saída de ouro] produziam as mudanças na renda e nos preços requeridas para ajustar o balanço de comércio", por outro lado, "na medida em que uma determinada variação das reservas [de ouro monetário] requeriam uma mudança múltipla nas obrigações bancárias, o processo normalmente envolvia uma variação nos termos em que os

(25) Veja-se, também, além de Viner (1937, p. 290-293); Laughlin (1903, p. 119-120); Bordo (1984, p. 33-35) e Flanders (1989, p. 7-13).

(26) Veja-se, além disso, Marshall (1887, p. 191); Whale (1937, p. 49); Triffin (1968 p. 24) e Allen (1992).

(27) Veja-se, por exemplo, os mecanismos descritos pelo Cunliffe Comimittee on Currency and Foreign Excheanges After the War, 1918. 
bancos emprestavam ${ }^{28}$ ou da taxa de desconto" (idem). Não foi sem motivo, pois, que "de acordo com a abordagem tradicional, um declínio (aumento) do estoque doméstico de moeda levava a uma elevação (queda) da taxa de juros e, consequentemente, atraía [repulsava] fundos do [para o] exterior" (Bordo, idem).

Não se pense, contudo, que, com essa última modificação, o mecanismo proposto por Hume estaria inteiramente descaracterizado, por incorporar os créditos bancários, "essa simulação de dinheiro que estrangeiros não aceitarão em nenhum pagamento e que será reduzido a nada por qualquer grande desordem do Estado" (Hume, 1752, p. 202) 29 $^{2}$. Essa perspectiva foi assumida por Viner (1937, p. 191-194), segundo o qual o mecanismo se aplicaria somente a uma situação em que o meio circulante consistisse "somente de uma moeda metálica padrão" (Viner, p. 290), como, por exemplo, libras esterlinas. Contudo, registre-se, de saída, que, à época em que Hume escreveu seus ensaios sobre temas econômicos, há muito que, no Reino Unido e em outras regiões da Europa, como nos Países Baixos e na Itália, as letras de câmbio, veículos por excelência do crédito comercial, circulavam amplamente (Eichengreen, 1984, p. 39-41), lado a lado com as notas bancárias conversíveis. Ademais, segundo Cameron (1967a, p. 20), por volta de 1754 existiam na Inglaterra, além do Banco da Inglaterra e perto de 10 bancos provinciais, 29 bancos privados em Londres. Já na Escócia, haviam, em 1750, 13 bancos, sendo que, desses, 5 emitiam notas conversíveis (Cameron, 1967b, p. 66). Não parece possível que, a Hume, tenham passado despercebidos esses fatos, até porque suas palavras mostram que não, quando afirma que "as instituições dos bancos, fundos e papel moeda" "tomam o papel equivalente à moeda, circulam-no através de todo o Estado, fazem-no ocupar o lugar do ouro e da prata, elevam proporcionalmente o preço da mão de obra e das mercadorias e, desse modo, eliminam grande parte daqueles metais preciosos, ou impedem seu crescimento posterior" (Hume, 1752, p. 221).

É claro que, conforme visto na seção 2, a arbritage via taxa de juros, ainda que pudesse existir em meados do século XVIII, funcionaria precária e lentamente, na melhor das hipóteses, mas mesmo assim o mecanismo de Hume não funcionaria, em razão da lei de refluxo de Adam Smith, que será discutida na seção 4. Na verdade, a que a tese de que a teoria de Hume se aplica exclusivamente a uma economia em que o único meio de circulação é a moeda metálica parece necessária para torná-la compatível com a proposição, sustentada em seu ensaio "Sobre os Juros" (p. 209215), mas contrária a vários contemporâneos seus, de que não existiria relação entre a taxa de juros e a oferta de meios de circulação (crédito). Aliás, o próprio Hume

(28) Ou seja, dos prazos, garantias requeridas e demais condições cadastrais, além dos recursos alocados para empréstimo.

(29) Nesta passagem, não fica claro se, por Estado, Hume quer dizer setor público ou país. No primeiro caso, estaria confundindo papel moeda inconversível ou letras de crédito emitidas pelo Tesouro, que perderiam valor diante de uma "grande desordem" das finanças públicas, com cédulas bancárias conversíveis, que estariam imunes. 
(p. 210) termina por admiti-lo, quando assevera que, além dos "lucros do comércio", os fatores determinantes da taxa de juros seriam a "demanda de empréstimos" e as "riquezas para suprir tal demanda". Registre-se, de mais a mais, que a relação entre taxa de juros de demanda por crédito não apenas seria consagrada, mais tarde, pelos economistas clássicos, desaparecendo somente quando da "revolução marginalista", que, na tentativa de preservar a coerência de sua construção teórica, transformou a taxa de juros em uma variável "real", que iguala poupança e investimento.

Seja como for, a taxa de juros terminou por ser incorporada ao mecanismo de ajustamento do balanço de pagamentos, inclusive do prevalecente durante o padrão-ouro, como, aliás, o reconheceu o próprio Viner, que, em sua obra de 1937 (p. 291), declara que “a teoria 'clássica' dos mecanismos do comércio internacional, conforme desenvolvida de Hume a J. S. Mill, ainda é, em suas linhas gerais, a teoria predominante" e "mais do que isso, nenhum mecanismo muito diferente foi sugerido de forma convincente" 30 . Para todos os efeitos, portanto, a discussão sobre se os mecanismos tradicionais do fluxo de metais/ajuste de preços de Hume refletem fidedignamente ou não o autor que lhe deu o nome, é imaterial para os efeitos da discussão encetada neste estudo.

Com base nessas considerações, pode-se, pois, representar esquematicamente o modelo de ajustamento da seguinte maneira. Na hipótese de um desequilíbrio não passageiro na balança de comércio exterior, possível graças à invariabilidade da taxa de câmbio, o país com superávit receberia ouro, ou seja, acumularia reservas monetárias, que permaneceriam ociosas caso os bancos comerciais não expandissem seus empréstimos. Para fazê-lo, os bancos teriam de ampliar os prazos dos empréstimos, reduzir as garantias e cortar a taxa de desconto. A conseqüente expansão da oferta de moeda significaria aumento da demanda agregada, tendo um efeito positivo sobre a renda real e o nível de preços. Também a queda da taxa de desconto teria efeito similar, pois reduziria os preços a prazo. O aumento da renda, por sua vez, faria crescer as importações, o que seria reforçado pela elevação do nível de preços, a qual, num contexto de taxa de câmbio fixa, significaria queda dos preços relativos dos produtos do resto do mundo. Também haveria uma queda das exportações, pois as mercadorias produzidas no país ficariam mais caras, em razão da inflação doméstica. Haveria, portanto, uma redução do superávit da balança de comércio exterior, a qual perduraria até que houvesse um equilíbrio do balanço de pagamentos. Mas os bancos, contando com reservas crescentes, também poderiam reduzir a taxa de captação, o que impactaria negativamente a balança de capitais, que poderia tornar-se negativa, contribuindo, assim, também para o equilíbrio do balanço de pagamentos.

(30) Aliás, ainda em 1979, Fausten (p. 655) advertia que "uma literatura rapidamente crescente [sobre a abordagem monetária do balanço de pagamentos] apresenta a característica comum de aludir, em algum lugar, à linha de David Hume e à sua concepção do mecanismo de ajustamento". 
No caso de um déficit do balanço de pagamentos, haveria o contrário. Diante da perda de reservas, os bancos teriam de cortar seus créditos, o que requereria a elevação da taxa de desconto. A conseqüente redução da oferta de moeda e aumento dos juros impactariam negativamente a demanda agregada, causando sua queda e, com ela, a da renda e dos preços. A redução da renda causaria a queda das importações, enquanto a diminuição dos preços faria aumentar as exportações e cair as importações, favorecendo o equilíbrio das contas externas. A perda de reservas também poderia forçar os bancos a aumentar a taxa de captação, o que traria efeitos positivos sobre os fluxos de capital, contribuindo para equilibrar o balanço de pagamentos.

\section{As insuficiências dos mecanismos do fluxo de metais/ajuste de preços de Hume}

Comparando-se o modelo clássico do ajustamento do padrão-ouro às operações práticas do padrão no final do século XIX, não é difícil perceber que

o modelo e a prática nem sempre concordam entre si. Mesmo admitindo que qualquer modelo econômico é nada mais do que uma descrição aproximada das variáveis que procura explicar, aqui existem certas diferenças que são suficientemente fundamentais para nos fazer crer que o modelo clássico do padrão-ouro seriamente obscurece o quadro do que ocorreu no processo de ajustamento internacional do século dezenove (Scammell, 1968, p. 114) ${ }^{31}$.

De fato, mesmo incluindo-se, como o fez o Curnliffe Commitee Co $^{32}$ taxa de juros no mecanismo de Hume, o exame dos dados empíricos, conforme salientado por Triffin (1968, p. 25-34), revela que, (i) em lugar dos movimentos divergentes previstos pela teoria, observou-se uma "dose enorme de paralelismo (...) entre as flutuações das exportações e importações de qualquer país, bem como na tendência geral dos movimentos de comércio externo dos vários países” (p. 25); (ii) "igualmente impressionante" foi o "paralelismo global - e não a divergência entre os vários países em comércio" (p. 26); (iii) "os ajustamentos descendentes dos salários raramente atingiram uma amplitude bem grande, mesmo entre os países que mantinham a estabilidade das taxas de câmbio"; (iv) “as políticas de 'neutralização' estigmatizadas por Ragnar Nurkse como outra causa importante - juntamente com a crescente rigidez dos preços e salários - da queda do padrão-ouro não foram de maneira alguma uma inovação do pós-[Primeira] guerra” (p. 27); (v) "o impacto das taxas de desconto no amortecimento dos movimentos de capitais e nas alterações corretivas da concorrência

(31) Conforme nota Laulin (1903, p. 368), "há dificuldades evidentes para se usar a teoria clássica sempre quando tentamos explicar as condições modernas". Por "teoria clássica" entende Laulin a teoria de Ricardo e Stuart Mill, que, segundo ele, estaria "intimamente associada com a teoria quantitativa da moeda" (p. 368). As inadequações dessa teoria para explicar "as condições” modernas estão apresentadas às páginas 369 a 372. Nas palavras de Glasner (1989, p. 103), "há muito tempo que os economistas têm estado conscientes de que essa visão do padrão-ouro não tem concordado muito bem com os fatos”.

(32) Committee on Currency and Foreign Exchanges after the War, escrito para o Parlamento Britânico em 1918. Para um exame do mesmo, veja-se Flanders (1989, p. 67-74). 
do custo, era também muito menos geral e uniforme do que comumente se admite" (p. 28); (vi) "a importância dos movimentos internacionais de capital e de suas flutuações é às vezes obscurecida pela ênfase desproporcional que se dá às flutuações relativas de preços e custos como fator principal nos desequilíbrios dos balanços de pagamentos e sua correção" (p. 30) 33; (vii) "[a] configuração cíclica dos movimentos internacionais de capital (...) teve um impacto muito diferente nos países exportadores e importadores de capital" (p. 32) - como frisa Bloomfield, "as taxas de descontos de, praticamente, todos os bancos [centrais dos principais países] tendiam a subir e a cair junto", tendendo, assim, "a apresentar um grande paralelismo no decurso do ciclo mundial" (p. 34), em lugar de apresentar as divergências previstas pela teoria.

Além disso, de acordo com Whale (1937, p. 51-52), “a política de antes da [Primeira] Guerra de bancos centrais líderes dificilmente parece estar de acordo com os requerimentos de um padrão de ouro operando da maneira concebida pelas explicações clássicas" 34 . Embora vários desses bancos não tenham seguido as "regras do jogo", "todavia o sistema funcionou". Por outro lado, o nível nacional de preços estaria antes "determinado pelo sistema mundial de preços" em lugar da quantidade de moeda em circulação no país. Além disso, "claramente, o padrão-ouro era um sistema gerenciado e não um sistema quase automático do ponto de vista dos países individuais líderes. Tampouco sempre funcionou de forma suave conforme comumente se acredita. De tempos em tempos, emergiram situações várias exigindo medidas 'emergenciais' por parte dos bancos centrais e governo para salvaguardar a continuidade da conversibilidade da moeda" (Bloomfield, 1959, p. 60). De mais a mais, "não há evidência de que a 'disciplina monetária' exerceu efeitos de 'longo prazo’ significativos sobre o balanço de pagamentos, através de seus impactos sobre o nível doméstico da renda e dos preços comumente atribuídos" (Bloomfield, p. 61). Finalmente, a evidência histórica sugere que "as 'regras do jogo' tinham muito menos importância e influência que do de acordo com os estereótipos usuais" (Bloomfield, p. 61).

A explicação das gritantes divergências entre o que o modelo tradicional prevê e o que efetivamente se observou durante o período de vigência do padrãoouro, mesmo atendo-se à sua definição restrita, parece radicar, em primeiro lugar, nas inconsistências teóricas do modelo tradicional de ajustamento do fluxo de metais/ ajuste de preços, largamente inspirado, como visto na seção 3, em Hume. Os mecanismos desenvolvidos por esse autor, por sua vez, representam "uma simples aplicação da teoria quantitativa da moeda num contexto de comércio internacional e

(33) Segundo Whale (1937, p. 51), a evidência empírica aparentemente mostra que, "de fato, os movimentos de ouro de e para os Estados Unidos antes da [Primeira] Guerra são mais facilmente conectados às taxas de juros do que aos níveis de preços”.

(34) Como salientado por McCloskey e Zecher (1976, p. 358), "somente uns poucos bancos centrais, se algum, seguiram as putativas 'regras do jogo"'. 
seu financiamento" (Allen, 1992, p. 510), ou seja, admitem determinadas hipóteses relativas à identidade quantitativa, que, de maneira simplificada, poderia ser expressa da seguinte forma:

$$
\mathbf{p} \mathbf{x}=\mathrm{M}_{\mathrm{O}} \mathrm{V}_{\mathrm{O}}+\mathrm{M}_{\mathrm{C}} \mathrm{V}_{\mathrm{C}}
$$

onde p é o vetor-linha de preços; $\mathbf{x}$ o vetor-coluna das quantidades das mercadorias lançadas em circulação; $M_{0}$ o montante de moedas de ouro em circulação; $V_{0}$ a velocidade de circulação dessas moedas; $\mathrm{M}_{\mathrm{C}} \mathrm{o}$ montante de "moeda de crédito" em circulação; e $\mathrm{V}_{\mathrm{C}}$ a sua velocidade de circulação.

Em particular, a teoria quantitativa da moeda supõe que: (i) não há distinção qualitativa entre as moedas de ouro e a "moeda de crédito"; (ii) a "oferta de moeda" (ou seja, o lado direito da identidade) é independente da "demanda" (do lado esquerdo), ou melhor, os montantes de ouro e de "moeda de crédito" em circulação são independentes dos fatores que determinam a "demanda por moeda", em função das reservas bancárias e do comportamento dos bancos; (iii) as velocidades de circulação das moedas de ouro e da "moeda de crédito" são determinadas por fatores institucionais, sendo independentes, pois, das variáveis que determinam a "demanda" por moeda.

O primeiro problema com essa formulação diz respeito à errônea igualação entre dinheiro, que, segundo os economistas clássicos (Smith, Ricardo e Stuart Mill) e Marx, seria "uma mercadoria selecionada" (Hawtrey, 1919, p. 17) ${ }^{35}$ e a "moeda de crédito", que, conforme esclarece Marx, com razão, substituiria o dinheiro na circulação mercantil somente na medida em que os pagamentos se compensam. Por "moeda de crédito" se entende as promessas de pagamento que, como as letras de câmbio e os títulos do Exchequer, circulavam até o seu vencimento, ou, como no caso das notas bancárias conversíveis e dos créditos em conta corrente, até que alguém, por qualquer motivo, resolvesse convertê-las em dinheiro (ouro ou prata).

$\mathrm{Na}$ circulação mercantil, o crédito surge quando se separam o ato da venda do ato de recebimento da soma de dinheiro correspondente: o vendedor recebe em troca da mercadoria cedida apenas uma promessa de pagamento, transformando-se em credor, enquanto o comprador se transforma em devedor. A nota de venda se transforma em título de crédito, que pode ser transferido a terceiros ou dar origem a outros títulos - como a "letra de câmbio" - que pode circular, dependendo da confiança depositada no comprador ou mesmo vendedor, que a endossava. Mas com

(35) Para Marx (1867, livro I, cap. I, p. 78-79), o dinheiro é a mercadoria historicamente escolhida como "equivalente geral", ou seja, que serve de expressão do valor de todas as outras. Além disso, o dinheiro serve de meio de troca (ou de circulação) e de meio de entesouramento. Observe-se que os clássicos tomam o ouro como a mercadoria-dinheiro apenas por conveniência histórica, ou seja, pelo fato do ouro ter assumido esse papel no Reino Unido. Pode-se também considerar a prata sem nenhum prejuízo para a análise. 
o desenvolvimento das relações creditícias, emerge e se desenvolve um sistema de compensação de pagamentos, normalmente centralizado nos corretores de títulos comerciais (bill brockers) e nos bancos. Nessas verdadeiras casas de compensação, "bastará confrontar os créditos de A contra B, de B contra C, de C contra A e assim por diante, para até certo ponto se anularem reciprocamente como grandezas positivas e negativas. Assim, fica estando apenas um saldo a pagar" (Marx, 1867, livro I, cap. III, p. 152) e a "moeda de crédito" terá substituído o dinheiro como meio de circulação na medida em que os pagamentos se compensam.

O segundo erro da teoria quantitativa da moeda consiste em supor que a velocidade de circulação das moedas de ouro e, principalmente, da "moeda de crédito" sejam exógenas, ou seja, independentes do jogo entre a oferta e a demanda por moeda. O motivo é que, como ficará mais claro na seção 5, que retrata a experiência histórica concreta do Reino Unido com o padrão-ouro, na prática um "excesso de oferta" de moeda invariavelmente significava que os bancos e, no caso britânico, os bill brokers e as Casas de Desconto ampliavam a echéance - ou seja, os prazos dos empréstimos - o que se estendia ao crédito comercial, com os produtores e comerciantes também ampliando os prazos máximos de suas vendas a crédito. Havia uma queda, portanto, da velocidade da moeda, que demorava mais a refluir para os produtores e comerciantes e, destes, para as Casas de Desconto e para os bancos. O inverso ocorria num contexto de "excesso de demanda" por moeda - os prazos dos empréstimos eram reduzidos, o que significava um aumento da velocidade de circulação da "moeda de crédito".

O terceiro erro da teoria quantitativa está em supor que a "oferta de moeda" seja independente da "demanda", ou seja, do montante de mercadorias lançadas em circulação. Para começar, parece evidente que, no caso do crédito comercial, ou seja, das vendas a prazo entre produtores e comerciantes entre si, o montante da oferta de "moeda de crédito" era, como ainda é hoje, largamente determinado pela "demanda". Afinal, quanto maior fosse a produção, maior seria a disposição de se vender um montante a prazo maior do que anteriormente. Mas quanto maior a produção e a circulação de mercadorias, maiores seriam, também, os depósitos dos produtores e comerciantes nos bancos, que disporiam, assim, de mais recursos para emprestar. Da mesma forma, maior seria o valor das vendas a prazo e, portanto, o montante de letras de câmbio a serem descontadas nos bancos comerciais. Considerando-se que o desconto de letras de câmbio era negócio típico desse tipo de banco, que, conforme explicado por Adam Smith, não deveria se dedicar a outra atividade, como o empréstimo hipotecário e o financiamento do capital fixo, sob pena de colocar em alto risco o negócio, o crédito bancário apenas substituía o crédito comercial, sendo portanto, tanto quanto ele, determinado, em grande parte, pelo ritmo das atividades 
econômicas, ou seja, pela demanda ${ }^{36}$. Não é sem motivo, pois, que, durante períodos de recessão do século XIX, era comum ver-se os cofres bancários cheios enquanto os empréstimos e, portanto, a circulação baseada na "moeda de crédito" bancária (ou seja, notas bancárias conversíveis e créditos em conta corrente) mantinha-se em nível reduzido.

Mas um dos maiores erros da teoria quantitativa da moeda de Hume e, portanto, dos defensores do modelo do funcionamento do padrão-ouro baseado no mecanismo do fluxo de metais/ajuste de preços nela baseado consiste em ignorar a "lei do refluxo" de Adam Smith, que estabelece que, conforme esclarece Ricardo (1811, p. 5), os bancos "nunca poderiam emitir mais notas do que o valor da moeda metálica que teria circulado se não houvesse qualquer banco". De fato, "se esses tentassem exceder esse montante, o excesso retornaria imediatamente para ser convertido em espécie; porque nossa moeda [- libra de ouro - ], estando dessa forma com valor diminuído, poderia ser vantajosamente exportada e não poderia ser retida em nossa circulação" (Ricardo, p. 7) ${ }^{37}$.

Segundo Gontijo (2007, p. 425-426), a "lei do refluxo" funciona da seguinte forma:

qualquer excesso de oferta (demanda) de meios de circulação provoca uma elevação (queda) dos preços das mercadorias - inclusive dos lingotes de ouro e/ou prata -, levando à valorização (desvalorização) cambial e ao surgimento de um ágio (desconto) da mercadoria-dinheiro em relação ao papel moeda de igual valor nominal. Segue-se um processo de refluxo das notas bancárias, que são apresentadas nos bancos para serem convertidas em metal precioso, e de remessa de ouro e prata para o exterior, o que traz de volta a taxa de câmbio ao seu valor de paridade, faz desaparecer o ágio das moedas metálicas sobre as notas de mesma denominação e elimina o excesso de oferta (demanda) de meios de circulação. Como resultado, o ajustamento do balanço de pagamentos não se opera através da flutuação do nível de preços, mas, através do fluxo de metal do país deficitário para o superavitário, o que preserva o nível de preços, embora possa levar à contração (expansão) do nível de atividades econômicas.

É por essa razão que, como adverte Glasner (1985, p. 47), “a hipótese de que os teóricos clássicos usavam a teoria quantitativa da moeda para explicar a determinação do nível de preços sob conversibilidade" representa um "erro crítico". Para esses economistas, "no padrão-ouro, o nível de preços era determinado pelo valor do ouro, não pela quantidade dos balanços nominais" e, graças à lei do

(36) Conforme explica Smith (1776, Livro II, Cap. II, p. 267), “os retornos do capital fixo, em quase todos os casos, são muito mais lentos do que os do capital circulante; e tais despesas, mesmo quando feitas com a máxima prudência e discernimento, geralmente só dão retorno ao empresário depois de muitos anos, período excessivamente longo para um banco [comercial]”. Veja-se, também, Livro II, Cap. II, p. 265 e 268 e Cap. IV, p. 299-300.

(37) A respeito do exemplo de Hume, veja-se Smith (1776, livro II, Cap. II, p. 257). 
refluxo e ao movimento compensatório da velocidade de circulação da moeda, é necessário acrescentar, o nível efetivo de preços gravitava em torno do seu patamar de equilíbrio, ou, dito de outro modo, "a quantidade da moeda [era] uma variável endógena" (Laidler, 1981, p. 188) - a oferta se ajustava à demanda ${ }^{38}$.

\section{O processo de ajustamento no padrão-ouro na prática}

Na verdade, os mecanismos efetivos de ajustamento monetário prevalecentes durante o padrão-ouro estavam condicionados, em última instância, pela necessidade, por parte dos bancos de emissão, de manterem a sua solvência, o que significava, na prática, na manutenção da conversibilidade de suas notas bancárias. Não é sem motivo, pois, que Bloomfiled (1959, p. 60) salienta que "inquestionavelmente, a conversibilidade era o objetivo dominante" dos bancos centrais durante o período ${ }^{39}$.

Para atingir esse objetivo primordial, os bancos - particularmente os grandes bancos nacionais que, detendo ou não o monopólio da emissão de notas bancárias, centralizavam grande parte das reservas de dinheiro (ouro e/ou prata) - lançavam mão da manipulação da taxa de juros e das condições de crédito (prazos, limites quantitativos e elegibilidade de ativos), assim como de operações de open-market ${ }^{40}$ e de outros expedientes. As reações dos bancos às diferentes condições do mercado monetário, aliadas aos seus efeitos sobre essas mesmas condições, compunham os mecanismos de ajustamento próprios do padrão-ouro, que, como se verá, se conjugavam irremediavelmente com o pulsar do ciclo de negócios ${ }^{41}$.

Para entender esses mecanismos, suponha-se que, como resultado da acumulação de reservas, os bancos detenham um excesso de dinheiro (ouro e/ou prata) em seus cofres. Essa situação pode resultar de uma política deliberada dos bancos, como ocorreu nos dois anos que antecederam a retomada da conversibilidade da libra esterlina em 1821, período em que o Banco da Inglaterra acumulou ouro, restringiu seus empréstimos e manteve a taxa de desconto no seu limite legal máximo (5\%). Pode,

(38) Glasner (1989, p. 55) assinala que, segundo Adam Smith, "sob conversibilidade (...), o nível de preços não depende do montante de moeda que o sistema bancário produz; ele depende do valor do ouro". Veja-se, ainda, da página 51 à 56. Já Bordo (1984, p. 35), reconhece que "Ricardo, na tradição clássica, via a quantidade de moedas de ouro como determinada, no longo prazo, pelos seus custos de produção", mas não retira as conclusões necessárias desse fato. A respeito da teoria monetária de Smith, veja-se, também, Checkland (1975); Vickers (1975) e Laidler (1981).

(39) Nas palavras de Hawtrey (1938, p. 40), "a reserva é sempre o fator determinante".

(40) As operações de open market do Banco da Inglaterra significam, essencialmente, vender/comprar Letras do Exchequer, Consols e, depois de 1877, Letras do Tesouro. A respeito dessas operações, veja-se Scammell, 1968, p. 174.

(41) Para Hawtrey (1947, p. 87-92), devido às defasagens envolvidas, o padrão-ouro era defeituoso como controlador "automático" do crédito - daí ter sido intrinsecamente vinculado aos ciclos de expansão, auge, crise, contração e retomada. 
também, ser a conseqüência de superávits sucessivos no balanço de pagamentos, como ocorreu na Inglaterra em 1852, "quando realmente pela primeira vez a chegada de grandes quantidades de ouro australiano produziu uma pletora de fundos" (King e Gregory, 1936, p. 189). E, de fato, tendo observado, depois do restabelecimento da conversibilidade, em maio de 1821, que não havia qualquer movimento no sentido de resgatar as suas notas, o Banco da Inglaterra reduziu a taxa de desconto para 4\% e ampliou o prazo das letras aceitas para desconto de 65 dias para 95 dias (King e Gregory, 1936, p. 35; Scammel, 1968, p. 131), numa iniciativa que, até certo ponto, se tornaria "automática" no final do século XIX ${ }^{42}$. Ou seja, diante de um excesso de reservas, as instituições bancárias, particularmente os grandes bancos nacionais de emissão, cortavam as taxas de juros, tanto a taxa de captação quanto a taxa de desconto de letras de câmbio, e ampliavam os prazos dos empréstimos, tomando a iniciativa inversa quando as reservas caíam abaixo do nível considerado adequado ${ }^{43}$. As medidas tomadas pelos bancos comerciais eram acompanhadas pelos produtores e comerciantes, com o corte (ou aumento) da taxa de juros do crédito comercial e o aumento (ou redução) dos prazos concedidos. Outra conseqüência era a substituição do crédito comercial, veiculado através das letras de câmbio, pelo crédito bancário, e o contrário quando as taxas de desconto bancário eram aumentadas e reduzidos os prazos dos empréstimos ${ }^{44}$.

Mas se a ampliação dos prazos significa, ipso facto, queda da velocidade de circulação da "moeda de crédito", o seu efeito conjugado à queda da taxa de juros é o aumento dos empréstimos e, portanto, da demanda agregada. O motivo é que juros menores significam preços a prazo mais baixos, enquanto prazos mais amplos, se transferidos aos consumidores, implicam menor comprometimento da sua renda com as prestações. Também significam menores custos de carregamento e uma necessidade menor de capital de giro para os comerciantes e produtores, favorecendo a acumulação de estoques. Em qualquer caso, portanto, tem-se um aumento da demanda agregada, o que, a não ser em condições de estrita ausência de capacidade ociosa, certamente se traduz em aumento da produção e em majoração dos preços

(42) Como resultado do fracasso da taxa de juros de ajustar o balanço de pagamentos, o Banco adotou a "regra de Palmer" de 1832, segundo a qual o Banco da Inglaterra deveria abandonar as tentativas de controlar o crédito via taxa de desconto, mantendo sua taxa (a "taxa do Banco") inalterável e acima da taxa de mercado (King e Gregory, 1936, p. 77-82). Essa "regra" seria abandonada depois da crise de 1939.

(43) King e Gregory (1936) fazem inúmeras referências à arma da echéance do Banco da Inglaterra, a qual foi perdendo importância, mas sem nunca ter sido abandonada, durante o século XIX. Observe-se que, de mais a mais, mesmo o uso menos freqüente por parte do Banco da Inglaterra não significa que as outras instituições financeiras, notadamente as Casas de Desconto londrinas e os bancos "privados", inclusive os bancos rurais e os bancos corporativos, tenham abandonado esse importante instrumento de controle do crédito.

(44) King e Gregory (1936, p. 59) assinalam que, quando, em conseqüência da Lei de 1826, o Banco da Inglaterra abriu filiais nas províncias, a queda da taxa de juros causou uma "acentuada redução da circulação de letras [de câmbio] em Lancashire e um sensível acréscimo do montante de descontos" nos bancos. 
(Hawtrey, 1947. p. 27-28, p. 43-45). Por outro lado, a expansão da produção traz consigo o crescimento das importações de insumos, enquanto o aumento resultante da renda implica no aumento das importações de bens de consumo. A própria queda da taxa de captação, por outro lado, reduz a atratividade das aplicações domésticas vis a vis os títulos estrangeiros, impactando negativamente, pois, o mercado de capitais. A resultante pressão sobre o mercado cambial pode elevar a taxa de câmbio e, se essa atingir o "ponto" superior do ouro, haverá conversão de notas bancárias em ouro para remessa para o exterior, o que reduzirá a oferta doméstica de moeda e as reservas bancárias.

Em outras palavras, o próprio aumento da "oferta moeda" desencadeia forças que se traduziam no aumento da demanda por meios de circulação e no refluxo de parte do acréscimo da própria "oferta". De fato, em termos da identidade quantitativa acima, tem-se a queda da velocidade da circulação da "moeda escritural" $\left(\mathrm{V}_{\mathrm{C}}\right)$, o incremento da produção (x) e no próprio refluxo de parte do ouro e da "moeda de crédito" em circulação, de modo que, após o aumento inicial, havia uma queda de $\mathrm{M}_{\mathrm{o}}$ e de $\mathrm{M}_{\mathrm{C}}$. Certamente que se essas variações não fossem suficientes para equilibrar a oferta e demanda por meios de circulação, haveria uma elevação dos preços $(\Delta \mathbf{p}>$ 0). Essa inflação, contudo, conduziria, por efeito da "lei do refluxo" de Adam Smith, discutida na seção 4, à acelerada redução do meio circulante por conversão de notas bancárias em ouro, quer para ser remetido para o exterior, quer para entesouramento (Hawtrey, 1947, p. 59). A conseqüente queda das reservas bancárias forçaria os bancos a elevar as taxas de juros passivas e ativas, reduzir os prazos dos empréstimos e cortar seus créditos, o que, ao diminuir a oferta de meios de circulação, eventualmente conduziria ao restabelecimento do nível de preços anterior, determinado pela relação entre os custos de produção das mercadorias e o custo de produção da moeda padrão de ouro. A "oferta de moeda", portanto, era inteiramente endógena.

Nesse sentido, existiam mecanismos que garantiam o ajustamento, muito embora, conforme fica claro do estudo da história concreta, o funcionamento dos mesmos não era inteiramente automático, até porque, além de estar sujeito à discrição dos banqueiros e demais agentes econômicos, que poderiam e efetivamente cometeram "erros" cruciais, o equilíbrio era atingido, como diria Marx, através de desequilíbrios cíclicos, ou seja, por crises periódicas. Mais do que isso, não havia a necessidade de nenhuma legislação extraordinária, como no caso do Bank Act de 1844 (o Peel Act), que, baseando-se na Currency School, determinou, entre outras coisas, que, no país, somente o Banco da Inglaterra poderia realizar novas emissões de notas bancárias, as quais deveriam ser totalmente "lastreadas" em ouro ou até $£ 14$ milhões em dívida do governo. Aliás, num claro indício de seu caráter 
contraproducente, o Act teve de ser suspenso durante as crises de 1847, 1957 e 1866, de forma a evitar o seu agravamento ${ }^{45}$.

Para ser rigoroso, cumpre ressaltar que, antes da internacionalização do mercado financeiro ter tornado eficaz o processo de arbitrage de ouro e juros, causando a drástica redução dos prêmios de retorno dos ativos financeiros fora de Londres, os mecanismos de ajustamento do padrão-ouro já funcionavam antes, por mais precariamente que fosse. Com efeito, tão logo o Reino Unido retornou à conversibilidade da libra, em maio de 1821, o Banco da Inglaterra, conforme mencionado, reduziu a taxa de desconto e ampliou o prazo dos empréstimos. Como resultado, assistir-se-ia a uma "ampla especulação, estimulada parcialmente por uma série de boas safras, parcialmente pelo baixo retorno dos títulos governamentais, mas especialmente pelas finanças imprevidentes por parte dos bancos provinciais", estimulados, além disso, pela decisão do governo de estender por mais dez anos a circulação de notas de menos de $£ 5$ (Gregory; King, 1936, p. 35). Apesar da taxa de câmbio tornar-se desfavorável no outono de 1824, dando início a um constante dreno de ouro, o Banco da Inglaterra somente sentiu-se alarmado em fins de 1825, quando começou a restringir o desconto de letras de câmbio. A atitude do Banco ampliou o alarma do mercado, o que deu lugar ao pânico com a quebra, em novembro dos bancos Elford's, de Plymouth, e Wynthworth and Co., de Yorkshire, e da firma Pole, Thornton \& Co., em fins do ano. Diante do eminente "colapso completo do sistema de circulação", o Banco, sob a inspiração de Thomas Joplin, reverteu sua política, passando a descontar livremente letras de câmbio, a emprestar com base em warrants e Letras do Exchequer e a adquirir essas Letras, emitindo pequenas notas bancárias (Feavearyear, 1931, p. 220-223; Gregory; King, 1936, p. 36; Hawtrey, 1938, p. 18; Scammell, 1968, p. 131-132).

$\mathrm{Na}$ esteira da expansão dos bancos na forma de sociedades anônimas, autorizados em 1826, seguiu-se outra onda de expansão creditícia, que teve início em 1835, dois anos, portanto, depois do Bank Charter Act de 1833 isentar as notas promissórias e letras de câmbio de até três meses de prazo dos limites das Leis da Usura $^{46}$. O boom coincidiu com a venda de títulos em Londres pelos bancos norteamericanos, interessados em reforçar suas reservas, assim como o resgate de notas do Banco da Inglaterra por parte das instituições financeiras irlandesas, preocupadas

(45) Conforme nota Glasner (1989, p. 106), comentando a influência do Bank Charter Act de 1844, "em cada oportunidade, uma crise foi precipitada pelo dreno de ouro do Banco da Inglaterra. Em nenhum momento esse dreno ameaçou exaurir as reservas do Banco, mas apenas reduzi-las abaixo do mínimo legal [estabelecido pelo $A c t$ ]. Ao contrário, o pânico emergiu do receio de que o Banco não seria capaz de satisfazer às demandas por empréstimos, pois a falta de reserva [causada pelo mesmo] impediria a emissão de mais notas bancárias". Veja-se Glasner (p. 81-84; 99-104). Uma discussão mais detalhada das razões do fracasso dessa peça de legislação, para não falar na sua influência deletéria sobre o funcionamento do padrão-ouro, embora de assinalada importância, exigiria todo um artigo, de forma que será deixada para outra oportunidade.

(46) O limite de 5\% ao ano para outros títulos foi abolido em 1854 (Feavearyear, 1931, p. 234). 
com a possibilidades dessas notas não terem curso forçado em seu país. Pressionado pela perda de ouro, o Banco da Inglaterra elevou a taxa de desconto de 4\% para 4,5\% em julho de 1836 e para 5\% dois meses depois. Pouco tempo depois, o Banco da Inglaterra viu-se forçado a socorrer o Banco Central e Noroeste da Inglaterra, assim como muitas casas norte-americanas de Londres. Seguiu-se a reversão do fluxo de ouro, reforçado pela inflação na Bélgica e na França, tornando confiante a diretoria do Banco da Inglaterra, que, em princípios de 1838, enviou $£ 1$ milhão em ouro aos Estados Unidos e reduziu a taxa de desconto para 4\%, a qual foi mantida não obstante a elevação da taxa de câmbio de mercado e o ressurgimento das saídas de ouro em julho. Mas, com as pesadas importações de trigo e o fim da inflação nos países continentais, aumentou a saída de ouro em princípios de 1839 , forçando o Banco da Inglaterra a elevar a sua taxa de juros para 5\% em maio, $5 \frac{1}{2} \%$ em junho e $6 \%$ em agosto. Com a suspensão dos pagamentos por vários bancos rurais, o Banco da Inglaterra viu-se compelido a tomar emprestado $£ 2$ milhões do Banco da França, com os quais conseguiu finalmente restabelecer a confiança e reverter o fluxo de ouro (Gilbart, 1840; Macleod, 1855, v. II, p. 263-268; Feavearyear, 1931, p. 235240; King; Gregory, 1936, p. 77; Hawtrey, 1938, p. 18-19).

Entre 1842 e 1844, quando o Reino Unido ainda se recuperava da crise, observou-se grande influxo de ouro, e, com reservas superando $£ 15$ milhões, o Banco da Inglaterra, agora dividido, graças ao Peel Act, entre o Departamento Bancário e o Departamento de Emissão, reduziu a taxa de desconto de $4 \%$ para 21\%2\% em setembro de 1844. Além disso, ampliou os prazos dos empréstimos, mesmo sem quebrar a regra de somente descontar letras de câmbio de, no máximo, três meses, através da renovação automática dos papéis de maior prazo. Com o novo boom de formação de empresas ferroviárias (Feavearyear, 1931, p. 261; Scammell, 1968, p. 157), a elevação do nível geral de preços e a quebra da safra de batatas na Irlanda no ano seguinte, e nova quebra de safra em 1846, a provocar a elevação do preço do trigo e grandes importações desse cereal, verificou-se novo dreno de ouro do Banco da Inglaterra, cujas reservas caíram para $£$ 9,5 milhões em dezembro desse ano para $£ 3$ milhões em abril de 1847. No dia 8 desse mês, a taxa de desconto do Banco, que havia sido elevada nos meses anteriores, foi aumentada para 5\% e, uma semana depois, anunciou-se que essa taxa somente seria aplicável a letras a poucos dias do vencimento. O Banco também suspendeu a renovação de empréstimos e estabeleceu limites quantitativos para o desconto e anunciou, mais tarde, que o desconto de letras de câmbio seria cortado pela metade. Seguiu-se um período de grande pressão sobre o mercado monetário, mas reverteu-se o movimento do ouro, com as reservas do Banco da Inglaterra voltando a $£ 5$ milhões (Scammell, 1968, p. 152; Hawtrey, 1938, p. $21 ; 29-31)$.

$\mathrm{O}$ aparente retorno à normalidade, contudo, foi interrompido pela falência, em agosto, de muitas firmas que se haviam engajado na especulação com grãos, e, 
apesar da disposição do Banco da Inglaterra de emprestar contra títulos públicos, a crise se aprofundou em setembro, com a quebra de várias Casas de Desconto (bill brokers). A queda das reservas do Banco para $£ 3,4$ milhões provocou a interrupção dos empréstimos contra títulos governamentais, levando o pânico à Bolsa de valores. No dia 18 de outubro, a crise atingiu o setor bancário, com vários bancos suspendendo os pagamentos. Verificando que a confiança do público nas notas do Banco da Inglaterra não havia sido abalada, o governo autorizou-o, ao arrepio da Lei de 1844, a emitir notas "sem lastro", através de Carta do Tesouro, tornada pública no dia 25, prometendo solicitar ao Parlamento uma lei de indenização, caso necessário. Imediatamente, o Banco liberou seus empréstimos, elevando, ao mesmo tempo, a taxa de juros para $8 \%$ e, depois, para $9 \%$. Isto foi suficiente para eliminar a crise de confiança, com o término da corrida bancária, o restabelecimento do crédito e o refluxo do ouro (Feavearyear, 1931, p. 261-265; Hawtrey, 1938, p. 22-23; Scammell, 1968, p. 153).

Apenas alguns meses foram suficientes para que os negócios retornassem ao seu ritmo pré-crise, impulsionados pelo acelerado crescimento das exportações, que mais que dobraram nos dez anos seguintes, pela expansão do crédito, particularmente do proporcionado pelos bancos corporativos de Londres e pela queda da taxa de desconto de mercado e da taxa do Banco da Inglaterra, que a seguiu em seu movimento decrescente, mantendo uma margem positiva de $1 / 2 \%$. A taxa do Banco foi reduzida para $4 \%$ em janeiro de 1848 , para $3 \frac{1}{2} \%$ em junho e para $3 \%$ em novembro, apenas para ser cortada em mais $1 / 2 \%$ um ano depois. Após algumas variações irregulares, a taxa chegou a $2 \%$ em abril de 1852 , mantendo-se nesse patamar pelo resto do ano. Em 1853, em meio à elevação do nível de preços, assistiu-se à deterioração das condições do mercado monetário, com a elevação de ambas, a taxa de mercado e a taxa do Banco, a começar em janeiro de 1853, até que, em $1^{\circ}$ de outubro, atingissem $5 \%$. O aumento dos juros, contudo, não impediu que tivesse início um processo de drenagem de ouro, ampliado com o estouro da Guerra da Criméia, em março de 1854, quando, então, os preços estavam em queda. Para proteger as reservas, o Banco da Inglaterra aumentou a taxa de juros para $5 \frac{1}{2} \%$, o que resultou na redução do montante de descontos e na recomposição das reservas (Feavearyear, 1931, p. 267-268; Scammell, 1968, p. 179).

Diante do sucesso de sua política, o Banco do Inglaterra reduziu novamente a taxa de desconto para $3 \frac{1}{2} \%$ em junho de 1855 , mas desta feita "uma vasta especulação estava em progresso", pois "as descobertas de ouro haviam estimulado a produção em todas as partes do mundo" (Feavearyear, 1931, p. 268). Com a aproximação do fim da guerra, cresceu a demanda por crédito, ocasionando séria redução das reservas do Banco, que reagiu elevando a taxa de juros, que atingiu $6 \%$ em fins de outubro para letras de menos de 60 dias e para 7\% para letras de prazo superior. Com a drástica redução dos descontos e recuperação das reservas, a taxa de desconto foi reduzida, em 
maio de 1856 , para $4 \frac{1}{2} \%$, somente para ser elevada novamente para $7 \%$ em outubro, como conseqüência da renovação das saídas de ouro. A progressiva normalização do mercado, com a queda da taxa do Banco para 51/2\%, foi interrompida, em agosto de 1857, pela dramática queda dos preços dos títulos das companhias ferroviárias norte-americanas, o que levou consigo vários bancos dos EUA para a bancarrota. A crise contagiou o mercado britânico, abarrotado com títulos ferroviários norteamericanos, a partir de fins de setembro, quando as notícias chegaram em Londres. Perdendo reservas rapidamente, o Banco da Inglaterra elevou sua taxa de desconto para $6 \%$ no dia 8 de outubro, para $7 \%$ no dia 12 e para $8 \%$ no dia 19 , quando as reservas haviam caído para pouco mais do que $£ 4$ milhões. Enquanto os sistemas bancários escocês e irlandês eram sacudidos, o Banco da Inglaterra, tendo elevado a taxa de desconto para $9 \%$ no dia 5 de novembro, tentava, sem sucesso, vender títulos governamentais para repor suas reservas, em meio a falência de grandes Casas de Desconto e de bancos ingleses e escoceses. A nova elevação da taxa de desconto para $10 \%$ no dia 7 de novembro não acalmou o mercado e, diante do agravamento da crise, com as reservas do Banco abaixo de $£ 1,5$ milhão, o governo emitiu nova Carta no dia 11 de novembro, suspendendo a Lei de 1844. Apesar das reservas do Banco terem caído ainda mais, atingindo somente $£ 581$ mil no dia seguinte, a situação começou a melhorar lentamente, com o mercado aceitando os títulos governamentais colocados pelo Banco. No final do mês, já eram claros os sinais de melhoria da situação, tendo o mercado de câmbio e o fluxo de ouro virado a favor do Reino Unido (Feavearyear, 1931, p. 270-274; Hawtrey, 1938, p. 25-27; Scammell, 1968, p. 179-180).

Como resultado da Lei de 1856, que tornou livre a formação de sociedades por ações, gerou-se, a partir de 1862, verdadeira mania de formação de empresas, inclusive bancárias e Casas de Desconto e companhias de finanças, especializadas em lançamento de ações e levantamento de dinheiro para projetos públicos e privados. Nem mesmo as saídas de ouro, causadas pela "fome de algodão" resultante da Guerra Civil nos Estados Unidos (1861-1865), pela compra de gado da Irlanda e pela elevação do nível de preços, e a conseqüente elevação da taxa de descontos do Banco da Inglaterra, que saltou de 3\% em junho para 7\% em outubro de 1865 , foram suficientes para interromper o boom. Nos primeiros meses de 1866, contudo, quando a taxa de juros já estava em $8 \%$, as notícias sobre a situação falimentar de grandes empresas fizeram soar o alarma, que desembocou em crise aberta no dia 9 de maio, com a falência da empresa Overend, Gurney \& Co., considerada too big to fail. O Banco da Inglaterra reagiu, expandindo seus empréstimos a $9 \%$ e, no dia 12 de maio, para 10\% e obtendo, uma vez mais, uma Carta de Indenização, que suspendia os efeitos do Charter Act de 1844. Uma vez mais, cessou o pânico e, com ele, o afluxo de ouro, embora não as falências. No dia 16 de agosto, o Banco sentiuse suficientemente seguro para cortar a taxa de desconto para $6 \%$, numa iniciativa que seria repetida muitas vezes até 25 de julho de 1867, quando a taxa chegou a 
2\%, patamar em que permaneceria pelos próximos dezesseis meses (King; Gregory, 1936, p. 229-244; Feavearyear, 1931, p. 277-280).

Já então, conforme assinalado na seção 2, "a posição do Banco [da Inglaterra] internacionalmente (...) era de tal importância que os movimentos de ouro que nada tinham que ver com as condições monetárias internas" frequentemente [tinham passado] a compeli-lo "a tomar medidas de precaução" (Feavearyear, 1931, p. 276). Mais do que isso, devido à integração dos mercados financeiros e à posição privilegiada de Londres, a taxa de juros do Banco havia se tornado poderoso instrumento de atração/repulsão de ouro, contribuindo de forma decisiva para equilibrar o balanço de pagamentos, de modo que, ainda como apontado naquela seção, se poderia dizer que os mecanismos de ajuste do padrão-ouro, conforme discutidos na seção 3, estavam em pleno funcionamento. Nada disso, contudo, foi suficiente para alterar, de forma perceptível, a dinâmica dos acontecimentos ou para evitar o movimento cíclico da economia mundial inserida no padrão-ouro, que continuou conturbada por crises financeiras de grandes dimensões, as quais, conforme salientado, eram parte integrante do próprio mecanismo de ajustamento.

Na verdade, na sequência de novo movimento especulativo (Kindleberger, 1990, p. 312; 314-315), a próxima crise, que eclodiu com a queda da Bolsa de Valores de Viena, a 8 de maio de 1873, espalhando-se para a Alemanha, até se tornar, com o colapso da Bolsa de Nova York em setembro, a "primeira crise internacional significativa" (Kindleberger, 1989, p. 170) ${ }^{47}$ foi superada sem os traumas de 1866, mas, em compensaão, esteve associada à "Grande Depressão do Século XIX”, que, tendo começado em 1873, durou 11 anos. Poucos meses depois da sua eclosão, o comércio internacional passou a encolher, as exportações de capital da Inglaterra e da França praticamente cessaram, assim como o desconto de letras de câmbio internacionais por parte das casas de desconto bancário e dos bancos londrinos, causando um grande número de falências não somente na Europa e nos Estados Unidos, mas também nos países latino americanos (Marichal, 2011). Ainda em maio, o Banco da Inglaterra elevou a taxa de desconto, tendo o novo patamar durado quatro semanas, para depois dar lugar a duas reduções nas dez semanas seguintes, na crença de que a tormenta havia amainado. Com o pânico em Nova York, a Grã Bretanha perdeu expressivo montante de ouro a partir de 25 de setembro, provocando a reação do Banco da Inglaterra, que elevou a taxa de juros novamente, tendo ela atingido 9\% a 6 de novembro, um dia depois de forte queda da Bolsa de Londres (Schwartz, 1987, p. 273-274). Com a lenta superação da crise, sem que houvesse necessidade de se suspender o Bank Act de 1844, como em 1866, as reservas de ouro do Banco se recompuseram, tendo a taxa de desconto sido cortada por duas vezes em 1874.

(47) “A crise de 1873". 
Com a superação da depressão e a volta do crescimento econômico, nos últimos anos da década de 1880, o Banco da Inglaterra voltou a elevar a sua taxa de juros no outono e no inverno de 1889 , tendo a mesma atingido $6 \%$ em dezembro, na tentativa de deter a especulação com investimentos no exterior, particularmente na Argentina e no Brasil, e a conseqüente saída de ouro. O Banco, contudo, não foi bem sucedido, até porque a taxa de mercado não a acompanhou, nunca subindo acima de $43 / 4 \%$, tendo, na verdade, caído abaixo de $4 \frac{1}{2} \%$ em fevereiro de 1890 . Diante do insucesso, o Banco tomou medidas extremas, conseguindo administrar o caixa de vários órgãos públicos e semi públicos, que eram grandes emprestadores, e passado a recusar a renovação de empréstimos, quando não os sobretaxava em $1 \frac{1}{2} \%$ ou $1 \%$. A atuação decisiva o Banco, ao domar o processo especulativo durante os primeiros meses de 1890, parece ter sido importante, pois em novembro do mesmo ano o banco Barings Brothers, que havia subscrito a maioria das emissões do governo da Argentina, que foi deposto pela Revolução do Parque, que eclodiu em 26 de julho do mesmo ano, tornou-se insolvente. Apostando que, como de fato se verificou posteriormente, a Argentina não iria caminhar para o defaut, o Banco da Inglaterra, além de levantar $£ 17,25$ milhões no mercado para dar liquidez ao Barings, ainda obteve $£$ 1,5 milhão em ouro junto ao Banco Estatal da Rússia e mais £ 3,0 milhões com o Banco da França, de forma a reforçar suas reservas. Com isso, a crise pôde ser superada sem qualquer pânico (Feavearyear, 1931, p. 285-286; King; Gregory, 1936, p. 305-309; Jones; Pool, 1953, p. 254-255; Scammell, 1968, p. 188-190 e Mitchener; Weidenmier, 2007).

"Uma crise de caráter muito diferente afetou a City no outono de 1907, quando um violento pânico financeiro varreu os Estados Unidos, deixando atrás de si uma trilha de bancos arruinados" (Jones; Pool, 1953, p. 255). A súbita saída de ouro dos cofres de Londres, que financiaram 85\% dos $£ 20$ milhões importados pelos bancos norte-americanos, fez com que o Banco da Inglaterra, que foi surpreendido pelo pânico com somente $£ 30$ milhões em reservas, elevasse a taxa de desconto de $4 \frac{1}{2} \%$ para $7 \%$, sendo, dessa feita, ao contrário do que ocorrera em fins de 1889 e inícios do ano seguinte, seguido pelas outras instituições financeiras. Depois de terem atingido um nível crítico ( $₫ 700$ mil), as reservas do Banco puderam ser recompostas tão logo cessou o fluxo para os EUA. Embora, portanto, por um triz, o mecanismo de ajustamento através de variações da taxa de juros funcionou de modo adequado (Feavearyear, 1931, p. 287), confirmando a importância desse instrumento no novo cenário financeiramente integrado, que se estabeleceu a partir de fins da década de 1860 .

\section{Conclusão: o padrão-ouro na teoria e na prática}

Como se pode depreender da descrição do funcionamento efetivo do padrão-ouro no Reino Unido antes de 1914, em razão da necessidade de se manter 
a solvência dos bancos - em particular do Banco da Inglaterra, que centralizava grande parte das reservas de ouro do país - existiam mecanismos efetivos vinculando o nível das reservas bancárias, a taxa de juros, os prazos dos empréstimos, o nível de preços, a taxa de câmbio de mercado, o balanço de pagamentos e o nível das atividades econômicas. Como o Reino Unido não era um país produtor de ouro, esses mecanismos significavam, na prática, que, toda vez que havia um desequilíbrio no balanço de pagamentos, resultando na saída de ouro, desencadeava-se um processo que, ao fim e ao cabo, resultava no restabelecimento de um balanço equilibrado ou superavitário ${ }^{48}$. Reduções das reservas resultantes do entesouramento interno provocadas pela elevação dos preços e/ou pela desconfiança na solvência dos bancos também produziam um efeito semelhante.

Nesse processo de ajustamento do balanço de pagamentos, o papel desempenhado pelas variações do nível de preços, embora presente, era, ao contrário do preconizado pelo mecanismo de fluxo de metais/ajuste de preços de Hume, inteiramente instrumental, revertendo-se ao final do mesmo. Em outras palavras, não havia mudança permanente do nível de preços, que se mantinha estável e vinculado ao custo relativo de produção do ouro ao nível mundial. Funcionava efetivamente, pois, a lei do refluxo de Adam Smith, embora não na forma suave por ele prevista, mas, na maioria das vezes, através de movimentos violentos e perturbadores, ou seja, de crises periódicas. Aliás, uma característica marcante no período era a conexão entre o processo de ajustamento e o ciclo econômico, muitas vezes olvidada pela abundante literatura sobre o padrão-ouro ${ }^{49}$.

Essa vinculação, assim como o entesouramento/desentesouramento interno do ouro - importante elemento da "lei do refluxo" - explicam grande parte do paralelismo observado por Triffin entre o comportamento econômico dos principais países, em franco desacordo com a teoria tradicional. Certamente que, conforme aponta Hawtrey (1938, p. 47-54; 77-122) a “demanda interna" explica grande parte da discrepância entre as variações das reservas de ouro dos bancos britânicos, principalmente do Banco da Inglaterra, e o saldo das saídas/entradas desse metal no século XIX. Mas o grande fator determinante dessa "demanda interna" não era, conforme parece entender Hawtrey, a variação do montante de ouro em circulação, mas a variação do montante de ouro entesourado. Em outras palavras, quando, em

(48) Na verdade, nesse mecanismo era clara a existência de uma assimetria em relação às variações das reservas internacionais, pois a acumulação indefinida de metal monetário pelos bancos, embora pudesse resultar em ciclos de expansão econômica que eventualmente seriam interrompidos e mesmo revertidos, não criavam as tensões resultantes da perda de ouro e/ou prata. Em compensação, uma perda de metal monetário poderia esgotar as reservas dos bancos, tornando-os incapazes de manter a conversibilidade (Hawtrey, 1947, p. 38) e, portanto, sua própria solvência.

(49) Um exemplo de ajustamento sem crise é dado pelo movimento ocorrido em 1858 e 1859, quando a elevação da taxa do Banco da Inglaterra foi suficiente para interromper a drenagem de ouro e reequilibrar o mercado (Feavearyear, 1931, p. 276-277 e King; Gregory, 1936, p. 207). 
razão da elevação do nível de preços decorrente da expansão econômica, havia perda de reservas de ouro, essa não ocorria ao nível de um único país, até porque todos os países estavam conectados no mesmo processo cíclico. A perda, portanto, era geral e obviamente era igual ao entesouramento de ouro (e/ou prata) pelo público não bancário. Inversamente, quando, em razão da elevação da taxa de juros e/ou do processo deflacionário, reabasteciam-se os cofres bancários, isso se dava à custa dos tesouros do público ${ }^{50}$. Feita essa ressalva, está correto Hawtrey (1938, p. 46), pois, ao conceber "a manipulação da taxa do Banco no período de 1858 a 1914 como um método de regular o fluxo de ouro adicional para a circulação não somente no Reino Unido, mas no resto do mundo".

\section{Referências bibliográficas}

ANGELL, James W. (1925). The theory of international prices. New York: M. Kelley, 1965.

ALLEN, William R. Specie-flow mechanism. In: NEWMAN, Peter; MILGATE, Murray; EATWELL, John. The New Palgrave Dictionary of Money \& Finance, v. 3, N-Z, p. 509-511. London: MacMillan, 1992. 3v.

BALACHANDRAN, G. Power and markets in global finance: the gold standard, 1890-1926. Journal of Global History, 3, p. 313-335, 2008.

BARRO, Robert J. Money and the Price Level under the Gold Standard. Money and the Price Level under the Gold Standard. The Economic Journal, v. 89, p. 13-33, mar. 1979.

BERSCH, Julia; KAMINSKY, Graciela L. Financial globalization in the 19th century: Germany as a financial Center. Munique: Ludwig-Maximilians-University Munich and Munich Graduate School of Economics, Set. 2008. (Working Paper).

BLOOMFIELD, Arthur I. Gold standard. In: GREENWALD, Douglas (Ed.). Encyclopedia of economics. New York: McGraw Hill, 1981.

Monetary policy under the International Gold Standard: 1880-1914. New York: Federal Reserve Bank of New York, 1959.

BORDO, Michael D. The globalization of international financial markets: what can history teach us? Paper apresentado na conferência International Financial Markets: The Challenge of Globalization", na Texas A and M University, Texas, em 31 de março de 2000.

The gold standard, Bretton Woods and other monetary regimes: an historical appraisal. Cambridge, Mass: National Bureau of Economic Research, Apr. 1993. (NBER Working Paper, n. 4.310).

p. 23-119).

The Gold Standard: the traditional approach. In: BORDO; SCHWARTZ (1984,

(50) Veja-se o depoimento de Robert Giffen para a Gold and Silver Commission de 1886 (questão 625). 
BORDO, Michael D.; CHOUDHRI, Ehsan U.; SCHWARTZ, Anna J. Was expansionary monetary policy feasible during the Great Contraction? An examination of the Gold Standard Constraint. (NBER Working Paper, n. 7125). Reimpresso em Explorations in Economic History, v. 39, n. 1, p. 1-28, Jan. 2002.

; EICHENGREEN, Barry; KIM, Jongwoo. Was there really an earlier period of international financial integration comparable to today? Cambridge, Mass: National Bureau of Economic Research, Sept. 1998. (NBER Working Paper, n. 6738).

; KYDLAND, Finn E. The gold standard as a rule: an essay in exploration. (NBER Working Paper, n. 3367). Reimpresso em Explorations in Economic History, v. 32, p. $423-$ 464, Oct. 1995.

; SCHWARTZ, Anna J. (Org.). A retrospective on the Classical Gold Standard, 1821-1931. Chicago: The University of Chicago Press, 1984.

CALOMIRIS, Charles W.; HUBBARD, R. Glenn. International adjustment under the classical gold standard: evidence for the U.S. and Britain, 1879-1914. Cambridge, Mass: National Bureau of Economic Research, 1986. (NBER Working Paper, n. 2206).

CAMERON, Rondo. Banking development and economic development, some lessons from history. New York: Oxford University Press, 1972.

. England, 1750-1844. In: CAMERON; CRISP; PATRICK; TILLY (1967, p. 1559).

; CRISP, Olga; PATRICK, Hugh T.; TILLY, Richard. Banking in the early stages of industrialization. New York: Oxford University Press, 1967.

CANJELS, Eugene; PRAKASH-CANJELS, Gauri; TAYLOR, Alan M. Measuring market integration: foreign exchange arbitrage and the Gold Standard, 1879-1913. The Review of Economics and Statistics, v. 86, n. 4, p. 868-882, maio 2004.

CASSIS, Youssef. Introduction: comparative perspectives on London and Paris as International Financial Centres in the Twentieth Century. In: CASSIS; BUSSIÈRE (2005, p. 1-11).

; BUSSIÈRE, Eric (Ed.). London and Paris as International Financial Centres in The Twentieth Century. Oxford: Oxford University Press, 2005.

CECCO, Marcello. Gold standard. In: NEWMAN, Peter; MILGATE, Murray; EATWELL, John. The New Palgrave Dictionary of Money \& Finance, v. 3, N-Z, p. 509-511. London: MacMillan, 1992. 3v.

CHECKLAND, S. G. Adam Smith and the Bankers. In: SKINNER, Andrew S.; WILSON, Thomas. Essays on Adam Smith. Oxford: Clarendon Press, 1975. p. 504-523.

CHERNYSHOFF, Natalia; JACKS, David S.; TAYLOR, Alan M. Stuck on gold: real exchange rate volatility and the rise and fall of the gold standard, 1875-1939. Journal of International Economics, v. 77, n. 2, p. 195-205, 2009. 
CONANT, Charles A. (1815). A history of modern banks of issue. 5th ed. rev. e Ampl. New York e London: Putnam's Sons.

CONDLIFFE, John Bell (1950). The commerce of nations. London: George Allen \& Unwin, 1951.

COOPER, Richard. N. (1982). The gold standard: historical facts and future prospects. Brookings Papers on Economic Activity, v. 1, p. 1-45. Reimpresso em The International Monetary System. Cambridge (MA) e London: MIT Press, 1985, p. 43-86.

DAUDIN, Guillaume; MORYS, Matthias; O’ROURKE, Kevin H. Europe and globalization, 1870-1914. Paris: Observatoire Français des Conjonctures Économiques, Jun. 2008. (Document de Travail, 2008-17).

DUNBAR, Charles Franklin (Ed.). History of banking in all the leading nations. New York: The Journal of Commerce and Commercial Bulletin, 1896. 4v.

EDWARDS, G. W. (1938). The evolution of finance capitalism. New York: Longman.

EICHENGREEN, Barry. História e reforma do sistema monetário internacional. Economia e Sociedade, Campinas, v. 4, p. 53-78, jun. 1995.

. The gold standard since Alec Ford. Cambridge, Mass: National Bureau of Economic Research, 1989. (NBER Working Paper, n. 3.222).

Editor's introduction. In: EICHENGREEN, Barry (Ed.). The gold standard in theory and history. New York; London: Methuen, 1985. p. 1-35.

FAUSTEN, Dietrich K. The Humean origin of the contemporary monetary approach to the balance of payments. Quarterly Journal of Economics, v. 93, n. 4, p. 655-673, Nov. 1979.

FEAVEARYEAR, E. A. The pound sterling. Oxford: Carendon Press, 1931.

FLANDERS, M. June. International monetary economics, 1870-1960. Cambridge: Cambridge University Press, 1989.

FLANDREAU, Marc; ZUMER, Frédéric. The making of global finance 1880-1913. Paris: OECD, 2004.

FLOUD, Roderick; MCCLOSKEY, Donald N. (Ed.). The economic history of Britain since 1700. 2nd ed. Cambridge: Cambridge University Press, 1994. 3v.

FRIEDMAN, Milton. The supply of money and changes in prices and output. In: JOINT ECONOMIC COMMITTEE OF THE CONGRESS OF THE UNITED STATES, The relationship of prices to economic stability and growth. Washington: U.S.G.P.O, 1958, p. 171-187.

GILBART, James William. An inquiry into the causes of the pressure on the money market during the Year 1839. London: Longman, Orme, Brown, Green, \& Longmans, 1840.

GLASNER, David. Free banking and monetary reform. Cambridge: Cambridge University Press, 1989. 
GLASNER, David. A reinterpretation of classical monetary theory. Southern Economic Journal, v. 52, n. 1, p. 46-67. Jul. 1985.

GOETZMANN, William N.; LI, Lingfeng; ROUWENHORST, K. Geert. Long-term global market correlations. Cambridge, Mass: National Bureau of Economic Research, Nov. 2001. (NBER Working Paper, n. 8612).

GONÇALVEZ, Reynaldo; BAUMANN, Renato; PRADO, Luiz Carlos Delorme; CANUTO, Otaviano. A nova economia internacional. Rio de Janeiro: Campus, 1998.

GONTIJO, Cláudio. As duas vias do princípio das vantagens comparativas de David Ricardo e o padrão-ouro: um ensaio crítico. Revista de Economia Política, v. 27, n. 3, p. 413-430, jul./set. 2007.

HANNAH, L. The rise of the corporate capitalism. London: John Hopkins University Press, 1976.

HARROD, R. F. (1951). La vida de John Maynard Keynes. México: Fondo de Cultura Económica, 1958.

HAWTREY, R. G. (1847). El patron oro en la teoria e en la practica. Tradução de Ramon Verea Rial. Madrid: Aguilar, 1951. . (1932). A century of bank rate. New York: Augustus M. Kelley, 1962.

1950. . (1919). Currency and credit. London; New York e Toronto: Longman, Green,

HILFERDING, Rudolf. (1910). Finance capital. London: Routledge \& Kegan Paul, 1981.

HUME, David (1752). Escritos sobre economia. Tradução de Eugene Sara Albieri. In: PETTY, William; HUME, David; QUESNAY, François. Petty. Obras econômicas; Hume, Escritos sobre Economia; Quesnay, Quadro Econômico dos Fisiocratas. São Paulo: Abril Cultural, 1983.

HUNT, Bishop Carleton. The development of business corporation in England 1800-1867. Cambridge: Harvard University Press, 1924.

JEFFRYS, J. B. (1938). Trends in business organization in Great Britain since 1856. New York: Arno Press, 1977.

JEVONS, Stanley. La monnai et le mecanisme de l'echange. 2. ed. Paris: Gerner Bailliere, 1877.

JONES, G. P.; POOL, A. G. A hundred years of economic development in Great Britain. London: Gerald Duckworth \& Co, 1953.

KINDLEBERGER, Charles P. Historical economics. Art or Science? Berkeley: University of California Press, 1990. (1989). Manias, Pânico e Crashes. Porto Alegre: Ortiz, 1992. . A financial history of Western Europe. London: George Allen \& Unwin, 1984. 
KINDLEBERGER, Charles P. The formation of financial centers: a study in comparative economic history. Aug. 1973. (MIT Working Paper, n. 114).

KING, W. T. C.; GREGORY, T. E. History of the London discount market. London: Routledge, 1936.

LAIDLER, David. Adam Smith as a monetary economist. Canadian Journal of Economics, v. 14, n. 2, p. $185-200$, May 1981.

LANDES, David S. (1969). Prometeu desacorrentado: transformação tecnológica e desenvolvimento industrial na Europa Ocidental, de 1750 até os dias de hoje. Rio de Janeiro: Campus, 2005.

LAUGHLIN, J. Laurence. The Principles of Money. Londres: John Murray, 1903.

LÉVY, R. G. Banques d'Émission et Trésors Publique. Paris: Hachete, 1911.

LINDERT, Peter H. Key Currencies and Gold, 1900-1913. Princenton: Princenton University Press, 1969.

LOTHIAN, James R. Financial Integration over the Past Three Centuries. Apr. 2001. (Independent Institute Working Paper, n. 26).

. Changes in the degree of international financial integration over the past three centuries. Feb. 2001. Disponível em: http://ideas.repec.org/p/rtv/ceiswp/139.html. Acesso em: 18 ago 2012 .

- Capital market integration and exchange-rate regimes in historical perspective. Research in Banking and Finance, v. 1, p. 139-173, 2000.

MACLEOD, Henry Dunning. The theory and practice of banking. London: Longman, Brown, Green and Longmans, 1955. v. I.

MARICHAL, Carlos. An early global crisis: the financial and commercial collapse of 1873 and its impact on Latin America. Genebra: Universidade de Genebra, 2011. Paper apresentado em seminário promovido no dia 7 de abril.

MARSHALL, Alfred (1887). Memoranda and evidence before the Gold and Silver Comission. Reeditado em Official Papers. London: MacMillan, 1928, p. 17-196.

MARX, K. (1867-1893). O Capital. Tradução de Reginaldo Sant'Ana. Rio de Janeiro: Civilização Brasileira, s.d. 6v.

McCLOSKY, Donald N.; ZECHER, Richard J. How the gold standard worked, 1880-1913. In: FRENKEL, Jacob A.; JOHNSON, Harry G. The monetary approach to the balance of payments. Toronto: University of Toronto Press, 1976. p. 357-385.

MICHIE, Ranald C. The London and New York stock exchanges 1850-1914. London: Allen \& Unwin, 1987.

MITCHENER, Kris James; WEIDENMIER, Marc D. The Baring crisis and the Great Latin American Meltdown of the 1890s. Cambridge, Mass: National Bureau of Economic Research, Sept. 2007. (NBER Working Paper, 13.403). 
MOGGRIDGE, D. E. Problems in the history of international economy since 1870: the gold standard. Texto para Discussão No 160, Departamento de Economia da PUC-Rio, abr. 1987.

MOKYR, Joel; e STROTZ, Robert H. The second industrial revolution, 1870-1914. Evanston: Northwestern University, 1998. Mimeo.

MORGAN, Edward Victor; THOMAS, William Arthur. (1962). The stock exchange: its history and functions. New York: St, Martin's Press, 1971.

NEAL, Larry. The finance of business during the industrial revolution. In: FLOUD, Roderick; McClOSKEY, D. N. The economic history of Britain Since 1700. 2nd ed. Cambridge: Cambridge University Press, 1994.

NEELY, Chrktoplier J.; WOOD, Geoffrey E. Deflation and real economic activity under the gold standard. Federal Reserve of Saint Louis Review, p. 27-37, Sept./Oct. 1993.

PLESSIS, Alain. When Paris dreamed of competing with the city... In: CASSIS; BUSSIÈRE (2005, p. 42-54).

RICARDO, David (1811). High price of bullion. Reeditado em RICARDO, David, Economic essays. London: G. Bell and Sons, 1923. p. 3-60.

ROCKWELL JR., Llewellyn H. (Org.). The gold standard. Lexington: Lexington Books, 1985.

ROLFE, Sidney E.; BURTLE, James L. (1973). O sistema monetário internacional. Uma reinterpretação. Rio de Janeiro: Zahar, 1975.

ROLNICK, Arthur J.; WEBER, Warren E. Money, inflation, and output under Fiat and commodity standards. Journal of Political Economy, v. 105, n. 6, p. 1308-1321, Dec. 1997.

SARGENT, Thomas J.; WALLACE, Neil. A model of commodity money. Journal of Monetary Economics, v. 12, p. 163-187, Jul. 1983.

SAUL, Saul. Banking alliances and international issues on the Paris capital market, 18901914. In: CASSIS; BUSSIÈRE (2005, p. 119-150).

SCHWARTZ, Anna J. Money in historical perspective. Chicago: University of Chicago Press, 1987.

SMITH, Adam (1776). A riqueza das nações. Investigação sobre sua natureza e suas causas. Tradução de Luiz João Baraúna. São Paulo: Abril Cultural, 1983.

SCAMMELL, W. M. (1968). The working of the gold standard. Yorkshire Bulletin of Economic and Social Research, p. 32-45, May. Reeditado em EICHENGREEN, Barry (Ed.). The gold standard in theory and history. New York; London: Methuen, 1985. p. 103-119.

SERRANO, Franklin. Do ouro imóvel ao dólar flexível. Economia e Sociedade, Campinas, v. 11, n. 2 (19), p. 237-253, jul./dez. 2002.

STUART MILL, John. (1848). Princípios de economia política. Tradução de Luiz João Baraúna. São Paulo: Abril Cultural, 1983. 2v. 
TRIFFIN, Robert (1968). O sistema monetário internacional. Tradução de Hunfredo Cantuária. Rio de Janeiro: Expressão e Cultura, 1972.

VICKERS, Douglas. Adam Smith and the status of the theory of money. In: SKINNER, Andrew S.; WILSON, Thomas. Essays on Adam Smith. Oxford: Clarendon Press, 1975. p. 482-503.

. Studies in the theory of money 1690-1776. New York: Chilton Co., 1959.

VINER, Jacob (1937). Studies in the theory of international trade. New York: Kelley, 1965.

WHALE, P. B. (1937). The working of the prewar gold standard. Economica, p. 18-32, Feb. Reeditado em EICHENGREEN, Barry (Ed.). The gold standard in theory and history. New York; London: Methuen, 1985. p. 49-61.

YEAGER, Leland V. International monetary relations: theory, history, and policy. 2nd ed. New York: Harper \& Row, 1976. 